\title{
A process-based evaluation of dust-emitting winds in the CMIP5 simulation of HadGEM2-ES
}

\author{
Stephanie Fiedler ${ }^{1,2,3} \cdot$ Peter Knippertz ${ }^{1,4} \cdot$ Stephanie Woodward $^{5} \cdot$ Gill M. Martin $^{5}$ • \\ Nicolas Bellouin ${ }^{5,6} \cdot$ Andrew N. Ross $^{1} \cdot$ Bernd Heinold $^{7} \cdot$ Kerstin Schepanski $^{7}$. \\ Cathryn E. Birch ${ }^{8} \cdot$ Ina Tegen $^{7}$
}

Received: 14 January 2015 / Accepted: 27 April 2015 / Published online: 16 May 2015

(C) The Author(s) 2015. This article is published with open access at Springerlink.com

\begin{abstract}
Despite the importance of dust aerosol in the Earth system, state-of-the-art models show a large variety for North African dust emission. This study presents a systematic evaluation of dust emitting-winds in 30 years of the historical model simulation with the UK Met Office Earthsystem model HadGEM2-ES for the Coupled Model Intercomparison Project Phase 5. Isolating the effect of winds on dust emission and using an automated detection for nocturnal low-level jets (NLLJs) allow an in-depth evaluation of the model performance for dust emission from a meteorological perspective. The findings highlight that NLLJs are a key driver for dust emission in HadGEM2-ES in terms of occurrence frequency and strength. The annually and spatially averaged occurrence frequency of NLLJs is similar in
\end{abstract}

Stephanie Fiedler

stephanie.fiedler@mpimet.mpg.de

1 School of Earth and Environment, University of Leeds, Leeds LS2 9JT, UK

2 Institute of Meteorology and Climate Research, Karlsruhe Institute of Technology, Kaiserstrasse 12, 76131 Karlsruhe, Germany

3 Present Address: Max Planck Institute for Meteorology, Bundesstrasse 53, 20146 Hamburg, Germany

4 Present Address: Institute of Meteorology and Climate Research, Karlsruhe Institute of Technology, Kaiserstrasse 12, 76131 Karlsruhe, Germany

5 Met Office, Exeter EX1 3PB, UK

6 Present Address: Department of Meteorology, University of Reading, Reading RG6 6BB, UK

7 Leibniz Institute for Tropospheric Research, Permoserstrasse 15, 04318 Leipzig, Germany

8 MetOffice@Leeds, School of Earth and Environment, University of Leeds, Leeds LS2 9JT, UK
HadGEM2-ES and ERA-Interim from the European Centre for Medium-Range Weather Forecasts. Compared to ERAInterim, a stronger pressure ridge over northern Africa in winter and the southward displaced heat low in summer result in differences in location and strength of NLLJs. Particularly the larger geostrophic winds associated with the stronger ridge have a strengthening effect on NLLJs over parts of West Africa in winter. Stronger NLLJs in summer may rather result from an artificially increased mixing coefficient under stable stratification that is weaker in HadGEM2-ES. NLLJs in the Bodélé Depression are affected by stronger synoptic-scale pressure gradients in HadGEM2-ES. Wintertime geostrophic winds can even be so strong that the associated vertical wind shear prevents the formation of NLLJs. These results call for further model improvements in the synoptic-scale dynamics and the physical parametrization of the nocturnal stable boundary layer to better represent dust-emitting processes in the atmospheric model. The new approach could be used for identifying systematic behavior in other models with respect to meteorological processes for dust emission. This would help to improve dust emission simulations and contribute to decreasing the currently large uncertainty in climate change projections with respect to dust aerosol.

Keywords Dust emission - Nocturnal low-level jet · Geostrophic wind · Earth system model · Climatology · North Africa

\section{Introduction}

Mineral dust aerosol from deserts is an important element of the Earth system. Dust aerosol changes the radiation budget directly through scattering and absorption as well as indirectly through altering cloud characteristics 
and the atmospheric circulation (e.g. Sokolik and Toon 1996; Rosenfeld et al. 2001; Lohmann and Feichter 2005; Tompkins et al. 2005; Karydis et al. 2011; Schmechtig et al. 2011). In addition to these climate effects, suspended dust aerosol decreases the air quality with adverse influences on human health (e.g. Longueville et al. 2010; Griffin 2007). Further impacts of dust include the disruption of air and road traffic due to reduced visibility and solar energy production due to suspended or deposited dust. Mineral dust also has fertilizing effects on terrestrial and marine ecosystems near and far away from dust sources (Okin et al. 2004; Jickells et al. 2005; Mahowald et al. 2005; Shao et al. 2011; Schulz et al. 2012). The major source region for mineral dust on Earth is North Africa, from where it can be transported across the Atlantic and Mediterranean basins (e.g. Prospero 1996; Kallos et al. 2006). Despite the impacts of North African dust aerosol, estimates of both the emitted dust amount (Ginoux et al. 2001; Tegen et al. 2002; Cakmur et al. 2004; Zender et al. 2004; Tanaka and Chiba 2006; Schepanski et al. 2009; Huneeus et al. 2011; Shao et al. 2011) and its climatic effects remain amongst the largest uncertainties in the present understanding of the Earth system (e.g. Boucher et al. 2013; Mulcahy et al. 2014).

Studies investigating aerosol-climate effects and estimating the atmospheric dust load are often based on global aerosol-climate models. Inter-comparing dust emission estimates from those models show differences of a factor of five to six (e.g. Textor et al. 2006; Huneeus et al. 2011). Globally, dust emission estimates in the AeroCom intercomparison for the year 2000 range from 500 to $4400 \mathrm{Tg}$ per year, affecting the mean aerosol optical depth (AOD) with values ranging from 0.02 to 0.053 at $550 \mathrm{~nm}$ (Huneeus et al. 2011). The model spread in North African dust emission amounts is even larger with 400 to $2200 \mathrm{Tg}$ per year (Huneeus et al. 2011), partly resulting from the lack of observations of the dust emission amount.

Determining the dominant reasons for the spread in stateof-the-art dust emission simulations is complicated due to the different processes involved and feedbacks within coupled Earth system models. Martin and Levine (2012) show that the vegetation die-back in an Earth system model increases the bare soil fraction so that more dust aerosol is emitted from previously sparsely vegetated areas in Africa. Emissions can be increased in this case through both more potential dust sources and stronger near-surface wind speeds due to a smaller surface roughness. The vegetation decrease is caused by a rainfall deficit during the West African monsoon which is displaced southward. Such feedbacks of rainfall biases could also be present in other Earth system models. For instance, Evan et al. (2014) show that the dust aerosol life-cycle in CMIP5 simulations is substantially different to observations. A systematic analysis of the reasons for differences in dust emission from Earth system models is missing. Textor et al. (2006) suggest that dust emission in models varies because of different wind speed distributions which influence dust emission non-linearly. This may not be a simple consequence of the coarse resolution, but due to different representations of meteorological processes leading to dust emission. For instance, in 40-day simulations for summer 2006 with the UK Met Office model, the coarsest configuration (40 km horizontal resolution) has surprisingly the largest wind speeds, due to a different development of synoptic-scale conditions (Marsham et al. 2011, 2013). Heinold et al. (2013) use the same model setup to investigate meso-scale processes. Their results suggest that dust emission associated with nocturnal low-level jets (NLLJs) and convective dust storms (haboobs) during summer 2006 are also represented differently. Since the results from these studies are derived from 40 days of data, their implication for long-term climate experiments is not clear. Principally, the model behavior with regard to meteorological processes for North African dust emission during other months is not well quantified.

The present work investigates the representation of meteorological processes for North African dust emission over 30 years simulated by the global Earth system model HadGEM2-ES from the UK Met Office. Previous work on HadGEM2-ES has shown global dust emissions at the upper end of the AeroCom range with $3311+/ 227 \mathrm{Tg}$ per year for particle sizes of $0.03-10 \mu \mathrm{m}$ (Bellouin et al. 2011; Huneeus et al. 2011). If larger dust particle sizes to up to $30 \mu \mathrm{m}$ are included, the global dust emission amount in HadGEM2-ES is even larger with $8000 \mathrm{Tg}$ per year (Bellouin et al. 2011). The associated large dust loads affect the model performance in AOD, which agrees only well with observations when mineral dust aerosol is absent (Bellouin et al. 2011). Collins et al. (2011) and Woodward (2011) show that HadGEM2-ES produces substantially more dust aerosol than the atmosphere-only model version HadGEM2-A, especially in the Sahel. This difference is assigned to (1) an increased fraction of bare soil due to vegetation die-back caused by a rain deficit and (2) higher near-surface wind speeds in the coupled model (Collins et al. 2011; Martin and Levine 2012). Further model improvements with regard to dust emission require a systematic approach for the evaluation of simulated processes. Especially the origin of the higher wind speeds in the coupled model system remains unclear. In the present study, the effect of the simulated winds on dust emission in North Africa is isolated to address the underlying meteorological mechanisms.

Here, HadGEM2-ES is run in the historical model configuration for 1980-2009 of the Coupled Model Intercomparison Project Phase 5 (CMIP5), the basis of the latest Assessment Report 5 (AR5) of the Intergovernmental Panel on Climate Change. The focus is set on the NLLJ as an important driver for dust emission in North Africa (e.g. Washington and Todd 2005; Schepanski et al. 2009; Fiedler 
et al. 2013; Heinold et al. 2013). NLLJs in North Africa can be formed by different mechanisms, namely inertial oscillations (e.g. Blackadar 1957; Knippertz 2008; Wiel et al. 2010), baroclinic conditions along the Saharan heat low (e.g. Parker et al. 2005; Bain et al. 2010; Pospichal et al. 2010) and interaction of the atmospheric flow with mountains (e.g. Washington and Todd 2005; Todd et al. 2008). Hourly output from HadGEM2-ES in combination with the automated detection tool for NLLJs by Fiedler et al. (2013) offers the unique opportunity to statistically analyze this dust-emitting process on sub-daily scales over a climatological time period of 30 years for new insights into the model performance. Since a long-term observational data set of dust emission does not exist, the dust emission climatology from the model by Tegen et al. (2002) calculated with wind speeds from ERA-Interim as in Fiedler et al. $(2013,2014)$ is used here as a benchmark. Quantifying the relative importance of NLLJs as a dust-emitting process from the models helps identifying systematic model behavior affecting dust emission, providing the basis for further advances in Earth system model development. Details of the method are outlined in the following Sect. 2. Results are presented in Sect. 3, followed by a discussion and conclusions from this work.

\section{Method}

\subsection{Models}

The Earth system model HadGEM2-ES is chosen for investigating the representation of dust-emitting winds. HadGEM2-ES was developed at the UK Met Office (Bellouin et al. 2011; Collins et al. 2011; Martin et al. 2011). It operates at a horizontal resolution of $1.875^{\circ} \times 1.25^{\circ}$ with 38 vertical levels up to $39 \mathrm{~km}$. The coupled ocean has a horizontal resolution of $1^{\circ}$ increasing to $1 / 3^{\circ}$ towards the equator and 40 vertical layers. While the temporal integration in the atmospheric component has a time step of $30 \mathrm{~min}$, the coupling to the ocean is hourly. The model is run in the historical CMIP5 setup (Bellouin et al. 2011; Jones et al. 2011) for the period 1980-2010 with hourly output (H2ES-I). In addition to the CMIP5 simulation, a sensitivity experiment with the atmosphere-only model configuration is analyzed for understanding model differences. The atmosphere-only configuration HadGEM2-A (H2ES-A) uses the observed vegetation cover from the "International Geophysical Biophysical Program" (Loveland et al. 2000). H2ES-A is compared against the experiment H2ES-C which has prescribed plant functional types of the interactive vegetation parametrization scheme from HadGEM2-ES. The experiment setup for H2ES-A (H2ESC) is the same as HadGEM2-A (HadGEM2-AE) in Martin and Levine (2012), but the data in this study captures two monsoon seasons (June to September) of the recent past with half-hourly resolution.

Climatologies of HadGEM2-ES are compared against ERA-Interim forecasts (Dee et al. 2011) which serve as the baseline climatology for model evaluation in the present study. Observational data of comparable quantity and quality are not available over most of North Africa. Instead of the six-hourly re-analysis product of ERA-Interim, shortterm forecasts of 12-h length are used as in previous works (Fiedler et al. 2013, 2014). Their advantage is the higher temporal resolution of three hours which is important for representing the diurnal cycle of wind speed and dust emission. The forecasted winds are close to the re-analysis product at 18, 00 and 06 UTC (Fiedler et al. 2013), which shows the best comparison against station observations over land amongst state-of-the-art re-analysis (Decker et al. 2012). The forecasts are initialized at 00 and 12 UTC and have a horizontal resolution of 1 degree. The geopotential height at $925 \mathrm{hPa}$ from ERA-Interim, the ModernEra Retrospective analysis for Research and Applications (MERRA Rienecker et al. 2011) from NASA, the Climate Forecast System Re-analysis (CFSR Saha et al. 2010) from the National Centers for Environmental Prediction (NCEP) and the re-analysis from NCEP/National Center for Atmospheric Research (NCAR Kalnay 1996) are compared to determine the uncertainty in re-analysis of the synopticscale conditions.

\subsubsection{Stable boundary layer}

The representation of NLLJs depends on both the pressure gradient force and the stably stratified boundary layer. In both ERA-Interim and HadGEM2-ES, the stable boundary layer is parameterized by a K-diffusion scheme (Brown et al. 2008; Sandu et al. 2013). The vertical turbulent flux $\overline{w^{\prime} \psi^{\prime}}$ of a given variable $\psi$ with the vertical wind perturbation $w^{\prime}$ is related to the vertical gradient of the variable's mean value multiplied by a turbulent exchange coefficient $\mathrm{K}$ parameterized as:

$K=l^{2} \frac{\partial \bar{\psi}}{\partial z} f(R i)$

where $l$ is the mixing length and $R i$ is the Richardson number. The gradient Richardson number $R i$ is defined by Stull (1988):

$R i=\frac{\frac{g}{\bar{\theta}_{v}} \frac{\partial \overline{\theta_{v}}}{\partial z}}{\left(\frac{\partial \bar{u}}{\partial z}\right)^{2}+\left(\frac{\partial \bar{v}}{\partial z}\right)^{2}}$

as a function of the gravitational acceleration $g$ and the vertical gradients in the mean virtual potential temperature 
$\overline{\theta_{v}}$, in the mean zonal and mean meridional wind components $\bar{u}$ and $\bar{v}$, respectively. This dimensionless number describes the ratio of the static stability and the vertical wind shear. Turbulent mixing occurs when $R i$ is below a critical threshold, typically values smaller than 0.4 (e.g. Banta et al. 2003). A long or short-tail function $f(R i)$ is implemented and artificially increases the vertical mixing in stable boundary layers so that higher nocturnal near-surface winds are simulated than observed (Brown et al. 2006, 2008; Sandu et al. 2013). Such an approach is applied to balance other model shortcomings so that an overall good forecast skill is maintained, e.g. regarding cyclone lifetime and near-surface temperatures, and justified by the currently poor representation of surface heterogeneity and sub-grid scale variability (e.g. Brown et al. 2008; Sandu et al. 2013). As a consequence the NLLJ strength is underestimated possibly affecting dust emission derived from this data (Fiedler et al. 2013).

ERA-Interim uses revised long-tail functions for momentum in the boundary layer (Louis et al. 1982; Viterbo et al. 1999), which is shown in Fig. 1 and given by:

$f(R i)^{\text {ERA-Interim }}=\frac{1}{1+10 R i(1+5 R i)^{-1 / 2}}, \quad R i>0$.

In HadGEM2-ES, long-tail functions are replaced by sharp functions in the climate configuration of HadGEM2-ES (e.g. Brown et al. 2008; King et al. 2001) given by:

$f(R i)^{\text {HadGEM2-ES }}=\left\{\begin{array}{cc}(1-5 R i)^{2}, & 0 \leq R i<0.1 \\ \left(\frac{1}{20 R i}\right)^{2}, & R i \geq 0.1\end{array}\right.$

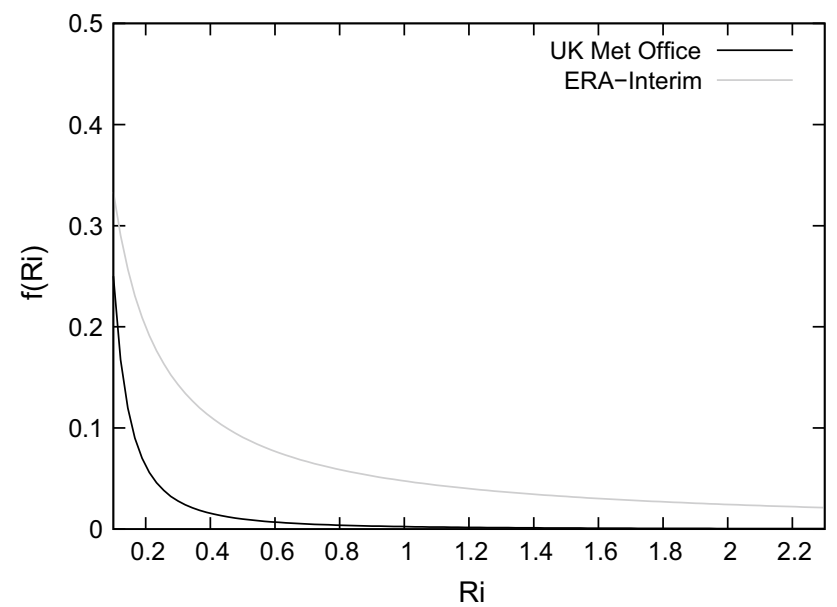

Fig. 1 Parametrization for momentum mixing. Shown is the dependency of the long-tail (ERA-Interim) and sharp (HadGEM2-ES) function on the Richardson number above values of 0.1 . The functions are applied for the momentum transport in the stable boundary layer
This function reduces the artificially enhanced mixing and thereby complies better with Monin-Obukhov similarity theory (Brown et al. 2008). The difference between both functions is shown in Fig. 1 for $R i \geq 0.1$, which are typical values for nights with NLLJs.

\subsubsection{Dust emission}

Dust emission in HadGEM2-ES is calculated interactively (H2ES-I) every time-step with the updated dust emission scheme by Woodward $(2001,2011)$. This parametrization is based on Marticorena and Bergametti (1995), where the saltation flux $F h_{i}^{\text {Woodward }}$ is calculated for each of 8 bins, with boundaries at particle radii listed in Table 1, following:

$F h_{i}^{\text {Woodward }}=\frac{\rho}{g}(1-V) u_{*}^{3}\left(1+U_{* t, i} / U_{*}\right)\left(1-\left(U_{* t, i} / U_{*}\right)^{2}\right) M_{i} C S$

Here, the subscript $i$ refers to the bin number, $\rho$ to the air density, $U_{*}$ to the surface friction velocity, $U_{* t, i}$ to the threshold friction velocity for the bin, and $M_{i}$ to the mass fraction of soil particles in the bin, $S$ to a preferential source term, $V$ to the fraction of vegetation cover per grid box, and $g$ to the acceleration by gravity. The constant of proportionality $C$ is set to 2.61 based on wind-tunnel experiments. Results by Bagnold (1941) provide the basis for the threshold friction velocities, which have been modified to account for the different spatial and temporal scales of HadGEM2-ES compared with the observations. The description of the effect of soil moisture is based on Fécan et al. (1999), modified to work in less arid areas by providing a moisture threshold above which particles cannot be emitted, and tuned to account for the soil-layer depth in the model. The vertical dust flux is calculated for 6 bins corresponding to the smallest 6 of the horizontal flux. The size distribution is that of the horizontal flux across these bins, but the total vertical flux is obtained from the total horizontal flux across all 8 bins, so that the ratio of the vertical to the horizontal flux agrees with the observations of Gillette et al. (1980). Thus for each of the first 6 bins listed in Table 1 the vertical flux $F v_{i}^{\text {Woodward }}$ is given by:

Table 1 Bins of particle-size radii in $\mu \mathrm{m}$ used in the dust emission schemes

\begin{tabular}{lll}
\hline Bin & Woodward $(2001,2011)$ & Tegen et al. (2002) \\
\hline 1 & $0.0316-0.1$ & $0.1-0.288$ \\
2 & $0.1-0.316$ & $0.288-0.871$ \\
3 & $0.316-1$ & $0.871-2.63$ \\
4 & $1-3.16$ & $2.63-7.94$ \\
5 & $3.16-10$ & $7.94-23.99$ \\
6 & $10-31.6$ & $23.99-72.44$ \\
7 & $31.6-100.00$ & $72.44-218.77$ \\
8 & $100.00-316.00$ & $218.77-660.69$
\end{tabular}




$$
\begin{aligned}
F v_{i}^{\text {Woodward }}= & 10^{\left(13.4 f_{c}-6.0\right)} F h_{i}^{\text {Woodward }} \\
& \times \sum_{i=1}^{8} F h_{i}^{\text {Woodward }} / \sum_{i=1}^{6} F h_{i}^{\text {Woodward }}
\end{aligned}
$$

where $f_{c}$ is the clay fraction of the grid box with a maximum of 0.2 . The effect of surface roughness on dust emission has been omitted in Woodward (2001). Potential dust sources are parameterized following Ginoux et al. (2001) with a preferential source term $\mathrm{S}$ that depends on the surrounding orography:

$S=\left(\frac{z_{\max }-z}{z_{\max }-z_{\min }}\right)^{3}$

with the local altitude $z$ and maximum (minimum) altitude $z_{\max }\left(z_{\min }\right)$ in the surrounding area of less than $10^{\circ}$ distance. The total vertical emission $F v^{\text {Woodward }}$ is given by:

$F v^{\text {Woodward }}=\sum_{i=1}^{6} F v_{i}^{\text {Woodward }}$

Dust-emitting winds from HadGEM2-ES will be compared against ERA-Interim. The latter does not provide dust emission data so that these are calculated with the dust model by Tegen et al. (2002) using three-hourly instantaneous 10m-wind speeds of ERA-Interim (T-EI-O) like in previous studies (Fiedler et al. 2013, 2014). This offline dust model and the scheme by Woodward (2001) are based on the same parametrization proposed by Marticorena and Bergametti (1995). However, they use different particle size distributions, potential dust sources, soil libraries and tuning settings. The scheme by Tegen et al. (2002) uses eight particle-size bins shifted towards larger particle radii (Table 1) which suggests a larger emission mass compared to the parametrization by Woodward (2001). The saltation flux $F h^{\text {Tegen }}$ in Tegen et al. (2002) is calculated for these bins by:

$$
\begin{gathered}
F h^{\text {Tegen }}=\frac{\rho}{g} u_{*}^{3} \sum_{i=1}^{8}\left[\left(1+\frac{u_{* t, i}}{u_{*}}\right)\left(1-\frac{u_{* t, i}^{2}}{u_{*}^{2}}\right) s_{i}\right], \\
u_{*}>u_{* t, i} .
\end{gathered}
$$

where $s_{i}$ is the relative surface covered by particle size $\mathrm{i}$. The vertical dust emission flux $F v^{\text {Tegen }}$ is calculated with:

$F v^{\text {Tegen }}=F h^{\text {Tegen }} A_{e f f} E_{\text {moist }} \alpha$

with the effects of soil moisture $E_{\text {moist }}$ and a scaling parameter $\alpha$ that is set to $10^{-5} \mathrm{~cm}^{-1}$ in potential dust source. $A_{\text {eff }}$ represents the vegetation-free fraction of a grid box potentially emitting dust given by:

$$
A_{\text {eff }}=1-4\left(V_{\text {max }} f_{\text {shrub }}+V_{\text {month }} f_{\text {grass }}\right) \text {. }
$$

This factor decreases with a growing fraction of shrub $f_{\text {shrub }}$ and maximum vegetation cover $V_{\max }$ as well as with the monthly vegetation cover $V_{\text {month }}$ and fraction of grass $f_{\text {grass }}$. Vegetation types are based on Kaplan (2001) and the soil size distribution on the Food and Agriculture Organization (FAO)/United Nations soil map of the World (Zobler 1986). Potential dust sources in the simulations with the Tegen et al. (2002) scheme are derived from the SEVIRI satellite product (Schepanski et al. 2007, 2009) as areas with at least two observed dust emission events (Fiedler et al. 2013, 2014; Heinold et al. 2013). The simulation with the Tegen et al. (2002) scheme use a surface roughness of $0.001 \mathrm{~cm}$ in potential dust sources, motivated by otherwise missed emission from observed dust sources in complex terrain. This lower surface roughness enables more emission from dust sources because less momentum is transferred to non-erodible obstacles so that more energy is available for particle mobilization.

A direct comparison of H2ES-I against T-EI-O would make it difficult to separate the effects of wind speed and the dust parametrization on the emitted dust amount. In order to reduce uncertainties for the desired intercomparison, the offline dust emission model by Tegen et al. (2002) is also run with instantaneous 10m-wind speeds from HadGEM2-ES (T-H2ES-O). Three-hourly results of T-H2ES-O are compared against the calculation with T-EI-O. Additionally, an offline dust emission calculation (T-ME-O) is driven with instantaneous $10 \mathrm{~m}$-wind speeds from MERRA. The seasonal mean dust emission from T-ME-O is shown along with T-EI-O to illustrate the spread in the best estimates of dust emission with state-of-the-art data sets.

The data sets used in this work are summarised in Table 2. Soil moisture is represented in H2ES-I but not included in the offline emission calculations here $\left(E_{\text {moist }}=1\right)$. The influence of soil moisture is limited to areas along the fringes of the Saharan desert (Fiedler et al. 2014). Other external driving data sets, e.g. potential dust sources, are chosen as in previous studies (summarized above, Fiedler et al. 2013, 2014; Heinold et al. 2013) and are the same for all offline calculations. This approach allows to assign differences in the offline dust emission calculations to the wind speed.

\section{Results}

\subsection{Dust emission}

Comparing the annually averaged dust emission amount in Table 2 shows substantial differences exceeding one order of magnitude. The largest total emission amount is simulated by H2ES-I with an annual mean of $4067 \mathrm{Tg}$. About 
Table 2 Overview of dust emission calculations for 1980-2009

\begin{tabular}{lllll}
\hline Experiment & Dust emission & Wind speed & Soil moisture & Total emission $\left(\mathrm{Tg} \mathrm{yr}^{-1}\right)$ \\
\hline H2ES-I & Interactive & HadGEM2-ES & Yes & 4067 \\
T-H2ES-O & Offline & HadGEM2-ES & No & 1947 \\
T-EI-O & Offline & ERA-Interim forecasts & No & 425 \\
T-ME-O & Offline & MERRA re-analysis & No & 280 \\
\hline
\end{tabular}

"I" in the experiment name refers to the interactive dust emission scheme by Woodward $(2001,2011)$ and "O" to the offline dust emission model by Tegen et al. (2002). The vegetation is described in Sect. 2 half of this emission amount is obtained with T-H2ES-O, namely $1947 \mathrm{Tg}$. T-H2ES-O is five times larger than the dust mass emitted by T-EI-O with $425 \mathrm{Tg}$ per year. Compared to T-ME-O with $280 \mathrm{Tg}$ per year, T-H2ES-O is even larger by about a factor of seven. Compared to the model intercomparison project by Huneeus et al. (2011) the total emission from T-EI-O (H2ES-I) lies at the lower (upper) end of the climate model spread for North Africa. Dust emission from T-EI-O has been evaluated with field and satellite observations in previous works (Fiedler et al. 2013, 2014). The evaluation shows a good agreement for the dust source activation frequency compared to satellite data from Schepanski et al. (2009) in most areas, but does not allow a direct conclusion on the emitted dust amounts (Fiedler et al. 2014). Using the classification of the dust storm severity observed in the Bodélé Depression during the BoDEx campaign (Todd et al. 2008) points to a good performance in dust emission magnitudes from T-EI-O (Fiedler et al. 2013).

Figure 2 shows the fraction of dust emission per season for H2ES-I and all offline dust emission calculations with the model by Tegen et al. (2002). T-EI-O produces $30 \%$ of its annual dust emission between December and February, $40 \%$ in March to May, $20 \%$ in June to August and a minimum of $10 \%$ between September and November. Dust

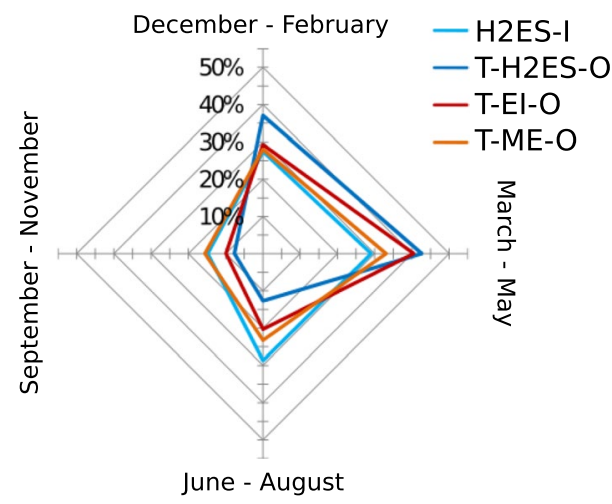

Fig. 2 Climatology of seasonal contributions to annual dust emission. Seasonal fraction of total dust emission based on (light blue) H2ES-I, (dark blue) T-H2ES-O, (red) T-EI-O and (orange) T-ME-O for 1980-2009 emission in T-ME-O agrees with the seasonal fractions for winter and summer, but has relatively less (more) emission in spring (autumn) by roughly $10 \%$. Seasonal fractions of dust emission from T-H2ES-O and H2ES-I should ideally lie within the spread between T-EI-O and T-ME-O of $10 \%$ in spring and autumn and $5 \%$ in winter and summer. H2ES-I shows a good agreement for winter and lies within the spread for autumn and spring. The summertime emission fraction, however, is overestimated by $10 \%$. Looking at T-H2ES-O gives a rather different perspective on the model performance for simulating the seasonal fractions of dust emission. While the fractions in spring and autumn from T-H2ES-O are within the spread of T-EI-O and T-ME-O, the seasonal fractions for summer and winter in T-H2ES-O are under- and overestimated by $10 \%$, respectively. In order to identify the regions with the largest differences, spatial patterns of the seasonal mean dust emission are analyzed next.

The spatial distribution of dust emission is shown in Fig. 3 averaged in units of $\mathrm{gm}^{-2}$ per season. In winter and spring, the largest dust emissions in H2ES-I are simulated for the southern fringes of the Saharan desert and parts of West Africa with seasonally $80-600 \mathrm{gm}^{-2}$ (Fig. 3a, b). These areas continue being active in the remaining months of the year, although peak emissions decrease to values below $100 \mathrm{gm}^{-2}$ per season in most areas (Fig. 3c, d). The dust emission from the Sahel is dominant in H2ES-I while little emission is produced in T-H2ES-O. Emissions from the Sahel in the coupled model are analyzed with the sensitivity experiment that uses prescribed plant functional types (H2ES-A) from Martin and Levine (2012). H2ES-A shows a reduction of dust emission in the western Sahel compared to H2ES-C for June to September (not shown). Earlier studies suggest an association with larger bare soil fractions due to a vegetation die-back in H2ES-I caused by a deficit of monsoon rainfall (Collins et al. 2011; Woodward 2011; Martin and Levine 2012; Birch et al. 2014). Interestingly, dust emission from the Sahel is even larger in winter and spring with around $100 \mathrm{gm}^{-2}$ per season in H2ES-I. Summer is, however, the season when the maximum is expected from T-EI-O and T-ME-O. The small emission over parts of Mali and Mauritania in H2ES-I coincide with small values of the preferential source term used in Woodward (2011). 


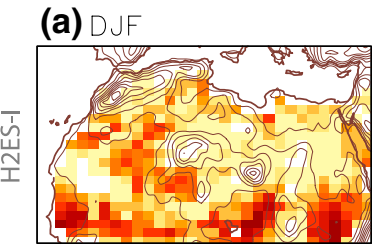

(e) $D J F$
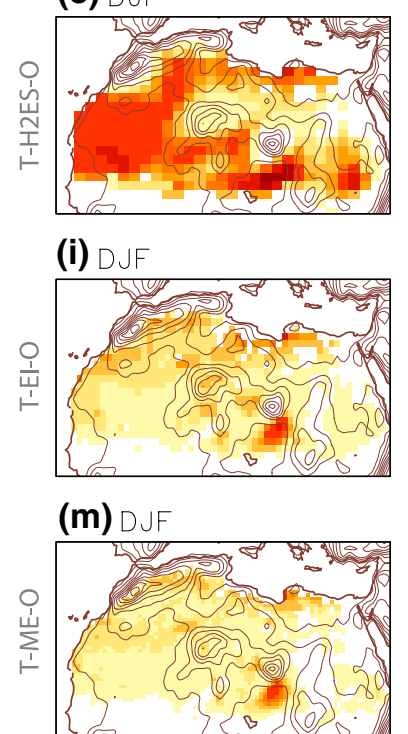

(b) MAM

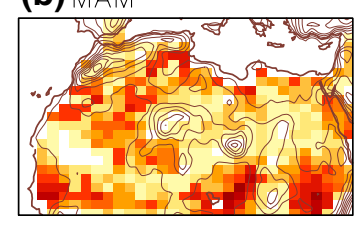

(f) MAM

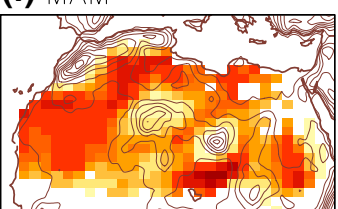

(j) MAM

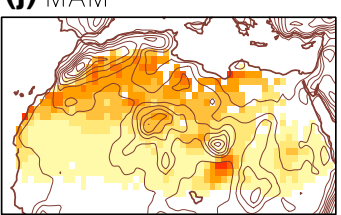

(n) MAM

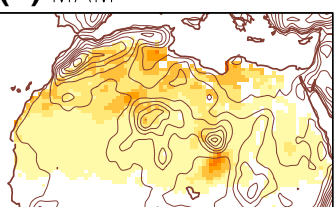

(c) $\lrcorner\lrcorner A$

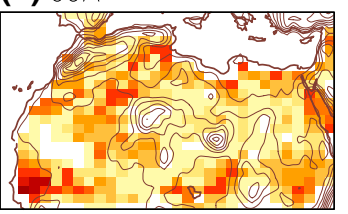

(g) $J J A$

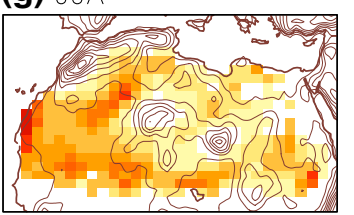

(k) $\mathrm{J} \mathrm{A}$

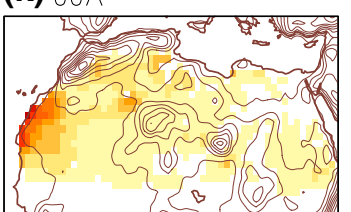

(o) $\mathrm{J} \mathrm{A}$

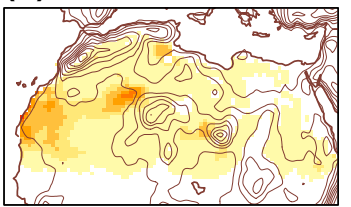

(d) SON

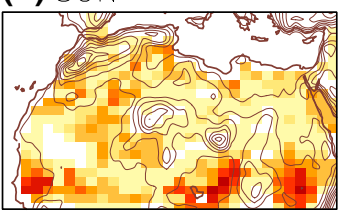

(h) SON

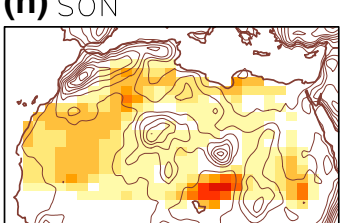

(I) $\mathrm{SON}$

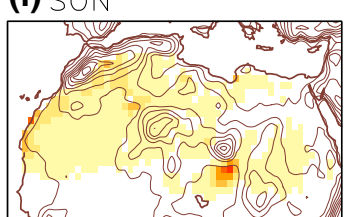

(p) SON

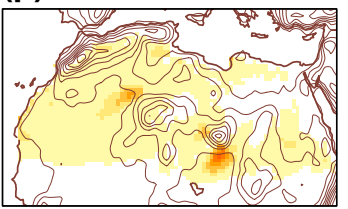

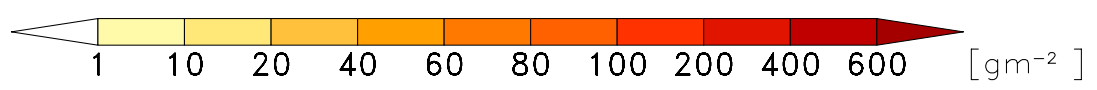

Fig. 3 Dust emission climatology. Seasonal mean dust emission for (from left to right) December-February, March-May, June-August and September-November based on (a-d) H2ES-I, (e-h) T-H2ES-
O, (i-l) T-EI-O and (m-p) T-ME-O for 1980-2009. Please note the non-linear scale for dust emission. Contours show the terrain height in steps of $200 \mathrm{~m}$
The Bodélé Depression, as an important African dust source, is active throughout the year with maxima of up to $600 \mathrm{gm}^{-2}$ between September and May in H2ES-I. Northern margins and the central Sahara have generally smaller maximum dust emission amounts of up to $400 \mathrm{gm}^{-2}$ in spring and summer (Fig. 3b, c).

The dust emission patterns in T-H2ES-O (Fig. 3e-h) are smoother than in H2ES-I. Peak emissions are mostly reduced to values of $100-200 \mathrm{gm}^{-2}$ in winter and spring (Fig. 3e, f). Similar to H2ES-I, dust emission in the Bodélé Depression remains comparably large between September and May with maximum emissions of seasonally 400$600 \mathrm{gm}^{-2}$. The dust maximum in winter and spring is more pronounced in T-H2ES-O with seasonally $60-80 \mathrm{gm}^{-2}$ over large areas in Mali, Mauritania and Algeria. Similar dust emissions are calculated for the northern fringes of the continent in winter that increase in some areas to seasonally 100-200 $\mathrm{gm}^{-2}$. Maximum emissions between June and November are smaller with $20-80 \mathrm{gm}^{-2}$ (Fig. 3g, h).

Compared to T-EI-O (Fig. 3i-l), the dust emission in T-H2ES-O are substantially larger throughout the year. The larger dust emission is most apparent in winter and spring over large areas of West Africa (Fig. 3i, j). Here T-H2ES$\mathrm{O}$ has widespread emission of seasonally $200 \mathrm{gm}^{-2}$ which is ten times larger than values in T-EI-O. Emissions in T-H2ES-O remain larger in summer and autumn with typically $60-100 \mathrm{gm}^{-2}$ per season compared to $10-40 \mathrm{gm}^{-2}$ in T-EI-O (compare Fig. $3 \mathrm{~g}$, h against $3 \mathrm{k}-\mathrm{l}$ ). T-EI-O and T-ME-O show the same spatial patterns for each of the seasons, although the latter has smaller peak emission in springtime North Africa and summertime West Africa. These differences are, however, small compared to the differences found between T-EI-O and T-H2ES-O. Also the general level of the dust emission amounts in T-H2ES-O is closer to H2ES-I than to T-EI-O. This result indicates that the wind speeds used in the same dust emission model have a larger impact on the calculated dust emission amount than differences between the dust emission parametrizations.

Possible differences of meteorological processes for dust emission in T-H2ES-O and T-EI-O are investigated in the following. The evaluation of T-H2ES-O is hereby entirely based on the comparison with T-EI-O and does not include 
T-ME-O. This choice is motivated by the larger number of dust-emitting winds at night and fewer during the day in MERRA (not shown). In comparison to ERA-Interim, MERRA has more frequent wind speeds of $6-9 \mathrm{~ms}^{-1}$ in winter and summer that are typically sufficient for dust emission. However, these winds occur primarily at night in MERRA pointing to even more frequent nocturnal events of downward momentum mixing than in ERA-Interim which has an artificially increased turbulent exchange coefficient under stable stratification. More nocturnal winds likely cause the larger dust emission over the northern areas of the continent in winter and in the west in summer. ERAInterim has more frequent events at the upper end of the wind speed distribution above $11 \mathrm{~ms}^{-1}$ in both seasons for all times of day which are likely connected to strong dust emission events. These are not represented in MERRA despite its higher temporal and spatial resolution. ERAInterim is therefore chosen as a benchmark for the model evaluation in the following. Dust emission from T-EI-O has been compared against observations (Fiedler et al. 2013, 2014) previously and is therefore not further validated here.

\subsection{Diurnal cycle}

The diurnal cycle of dust emission and 10m-wind speed provides first indications of the meteorological processes driving dust emission. Heinold et al. (2013) show that the downward mixing of momentum from NLLJs dominates the dust emission during the mid-morning while haboobs are the prevailing mechanism in the late afternoon and evening based on a 40-day convection permitting simulation for summertime West Africa. Nighttime emissions in these calculations are a mixture of both processes. The occurrence of haboobs is not expected in HadGEM2-ES because of the parametrization of convection (Marsham et al. 2013). In HadGEM2-ES, dominant emission around midday and in the afternoon may rather be linked to the downward mixing of momentum from a layer of high wind speed in the free troposphere when the daytime boundary layer is sufficiently deep. Nighttime and morning emission are expected to be linked to the vertical mixing of momentum from NLLJs (Fiedler et al. 2013). The diurnal cycle is used as an indication whether these mechanisms are responsible for larger dust emission in T-H2ES-O compared to T-EI-O.

The diurnal cycle of dust emission from H2ES-I, T-H2ES-O and T-EI-O as well as box-and-whisker plots of the near-surface wind speed from HadGEM2-ES and ERAInterim forecasts seasonally averaged for 1980-2009 are analyzed for the sub-domains S1 over parts of West Africa and S3 enclosing the Bodélé Depression. The geographical location of these sub-domains follows the definition in Fiedler et al. (2013) and are shown in Fig. 4. The analysis

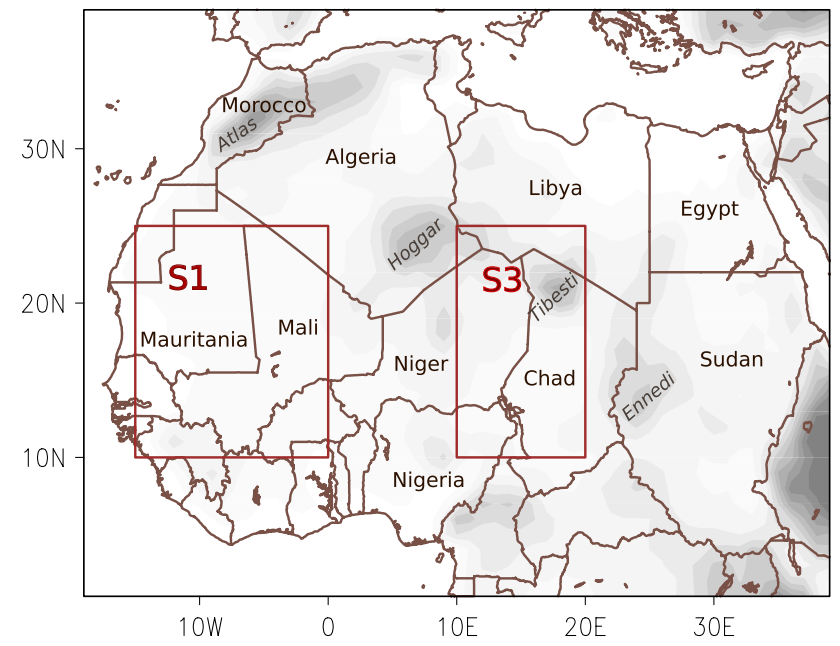

Fig. 4 Geographical map. Shown are the (shaded) terrain height in steps of $200 \mathrm{~m}$ from ERA-Interim, (brown contours) political borders and (red contours) location of sub-domains

highlights that the differences in the dust emission between T-H2ES-O and T-EI-O are substantially larger than the differences between T-H2ES-O and H2ES-I independent of the season and sub-domain (Fig. 5). The diurnal amplitude in dust emission from T-EI-O is often too small to be resolved by the vertical axis, but is shown on a different scale in Fiedler et al. (2013).

In $\mathrm{S} 1$, the overall largest differences in dust emission between T-H2ES-O and T-EI-O occur between December and May (Fig. 5a, b). While T-H2ES-O has peak emissions of $12 \mathrm{gm}^{-2}\left(8 \mathrm{gm}^{-2}\right)$ at 09 UTC (at 12 UTC) in winter (spring), emissions in T-EI-O do not exceed $2 \mathrm{gm}^{-2}$. H2ES-I has emissions closer to T-H2ES-O with differences of up to $2 \mathrm{gm}^{-2}$. The diurnal variations in summer and autumn are similar with peaks in the morning, although the magnitude is generally below $4 \mathrm{gm}^{-2}(5 \mathrm{c}, \mathrm{d})$. These mid-morning emissions point to NLLJs as the driving mechanism for dust emission. Also the diurnal variations of the near-surface wind speed have a clear maximum during the morning and at midday, the former of which supports the hypothesis of NLLJs as the driving mechanism for dust emission. The largest wind speeds, here shown by the $99 \%$-percentile of the $10 \mathrm{~m}$-wind speed, are $11 \mathrm{~ms}^{-1}$ at 09 UTC and $12 \mathrm{~ms}^{-1}$ at 12 UTC in HadGEM2-ES, compared to $8 \mathrm{~ms}^{-1}$ at 12 UTC in ERA-Interim. These winds are well above typical threshold values for dust emission onset. A perfect correlation between the wind speed and dust emission maxima, however, is not seen. For instance the largest wind speeds in HadGEM2-ES occur at 12 UTC, but the peak emission is earlier at 09 UTC. This can be due to surface properties that suppress dust emission in parts of the sub-domain, i.e. the high wind speeds at 12 UTC occur away from dust sources. As a result dust emission may not 
Sub-domain S1
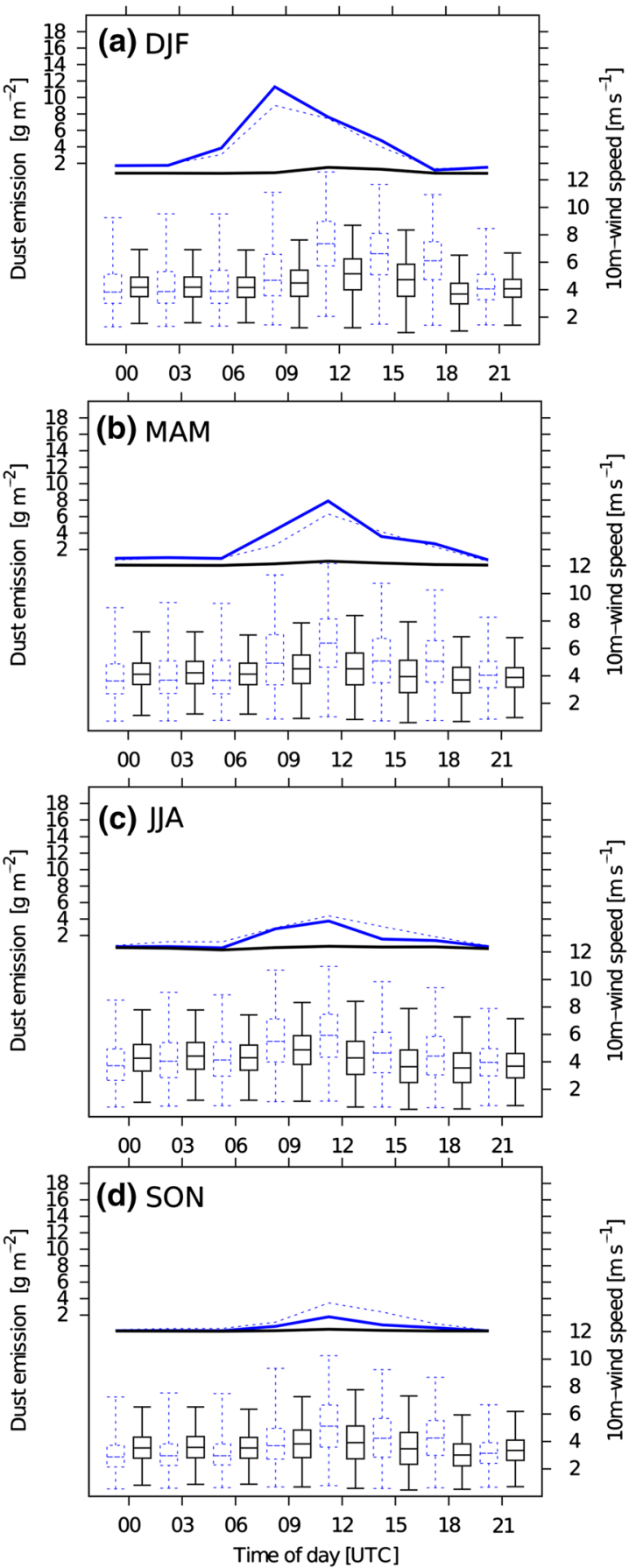

Fig. 5 Diurnal cycle of dust emission and 10m-wind speed per season. (Top) Dust emission from (dashed) H2ES-I, (blue) T-H2ES-O and (black) T-EI-O. (Bottom) box-and-whisker plots of the $10 \mathrm{~m}$-wind speed (dashed) from HadGEM2-ES and (solid) ERA-Interim for the sub-domain $\left(15^{\circ} \mathrm{W}-0^{\circ}, 10^{\circ} \mathrm{N}-25^{\circ} \mathrm{N}\right.$, a-d $) \mathrm{S} 1$ and $\left(10^{\circ} \mathrm{E}-20^{\circ} \mathrm{E}, 10^{\circ} \mathrm{N}\right.$
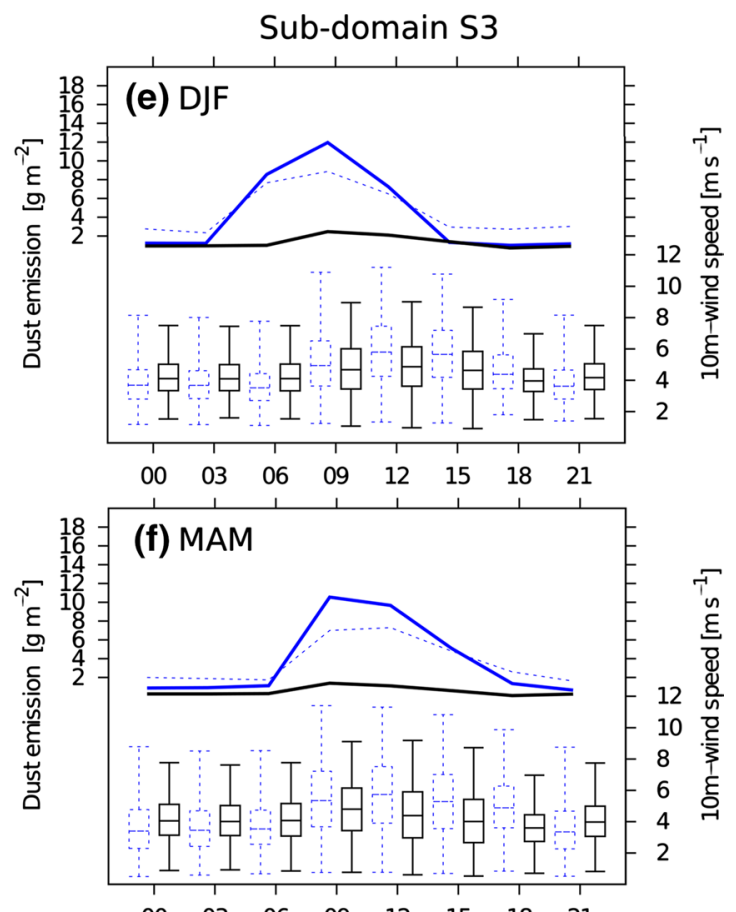

$\begin{array}{llllllll}00 & 03 & 06 & 09 & 12 & 15 & 18 & 21\end{array}$
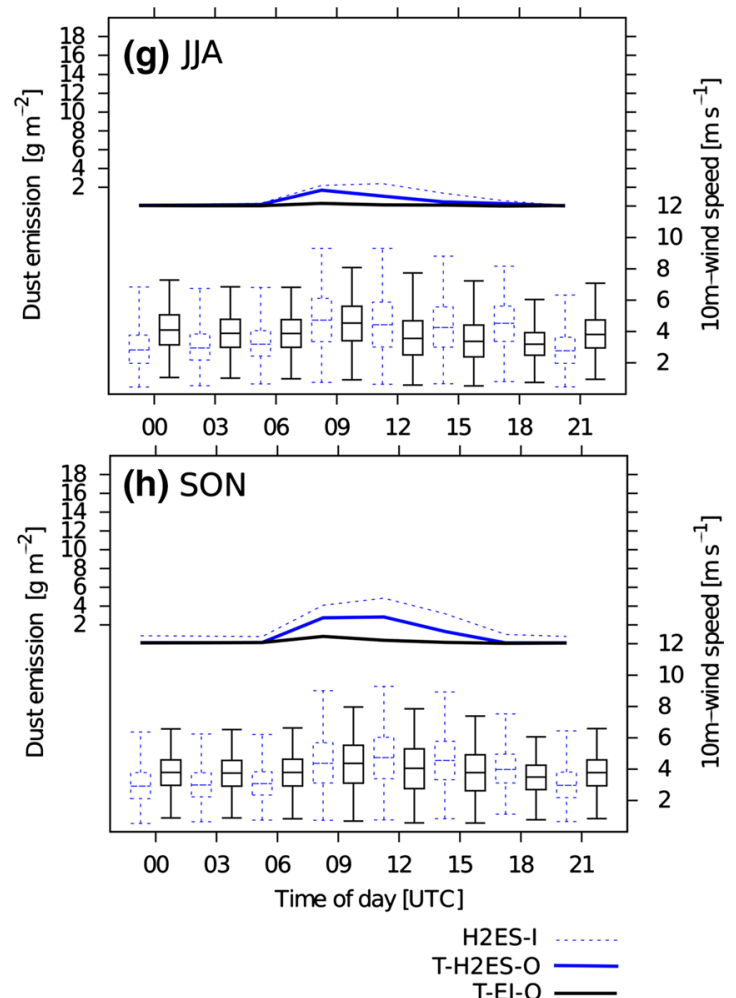

$\left.-25^{\circ} \mathrm{N}, \mathbf{e}-\mathbf{h}\right) \mathrm{S} 3$. Figure shows three hourly values spatially averaged for the sub-domains and the season (a, e) December-February, $(\mathbf{b}, \mathbf{f})$ March-May, (c, g) June-August and (d, h) September-November for 1980-2009. The geographical position of the sub-domains is shown in Fig. 4 and follows Fiedler et al. (2013) 
occur even if a sufficient wind speed is given at the grid point.

A similar diurnal cycle is found in the sub-domain S3 shown in Fig. 5e-h. Dust emissions are largest at 09 UTC in winter and spring with $12 \mathrm{gm}^{-2}$ in T-H2ES-O, $8 \mathrm{gm}^{-2}$ in H2ES-I and $3 \mathrm{gm}^{-2}$ in T-EI-O (Fig. 5e, f). The $99 \%$-percentile of the wind speed in HadGEM2-ES at that time is $11 \mathrm{~ms}^{-1}$ spatially averaged. Maxima from HadGEM2-ES are also found at 09 and 12 UTC in summer and autumn (Fig. 5g, h), but the dust emission amount from T-H2ES-O does not exceed 2 and $4 \mathrm{gm}^{-2}$, respectively. ERA-Interim has fewer events at the upper end of the 10m-wind speed distribution and also T-EI-O has much smaller dust emission amounts than T-H2ES-O.

In summary, the mid-morning maxima of both the $10 \mathrm{~m}$-wind speeds and the dust emission from T-H2ES-O, H2ES-I and T-EI-O in parts of West Africa for DecemberFebruary and the Bodélé Depression for December-August suggest that the NLLJ is a key driver for emission. Both regions have been identified for frequent NLLJ occurrence based on ERA-Interim (Fiedler et al. 2013). The NLLJ is further analyzed in the following Sect. 3.3. The midday maximum of dust emission and peak winds in parts of West Africa in spring points to strong synoptic-scale pressure gradients in the lower troposphere which will be addressed in Sect. 3.4.

\subsection{Representation of NLLJs}

The skill of ERA-Interim in NLLJ forecasting is tested with a contingency table using quality controlled radiosondes launched during the African Monsoon Multidisciplinary Analysis (AMMA, Redelsperger et al. 2006; Parker et al. 2008; Agust-Panareda et al. 2009). The longest record of radiosondes around 00 UTC is available at Agadez, Niger $\left(16^{\circ} \mathrm{N}, 7^{\circ} \mathrm{E}\right)$ for January-October, which is located in an area of frequent NLLJ formation. NLLJ presence at midnight in ERA-Interim is manually compared against its occurrence in the radiosonde data. Manual comparison has been chosen since the automated detection from Fiedler et al. (2013) is not directly transferable to the noisy radiosonde data. Some nights are missing in the observation record so that 242 nights are examined in total. Ten nights showed some ambiguity and are excluded from the statistics. The hit rate of 0.92 , the probability of detection of 0.96 , and the false alarm ratio of 0.04 indicate a good forecast performance for NLLJ events. However, the small sample size limited to one station and year does not allow to generalize this finding. Especially taking into account that the occurrence of NLLJs is a frequent event in both the model and the observation, the statistical assessment of the model skill is rather limited. More quality-controlled upper-air observations from North Africa are needed for reliably assessing NLLJs in the re-analysis over North Africa. In the absence of more observations, NLLJs from ERA-Interim are used as the benchmark.

\subsubsection{Occurrence frequency}

The diurnal cycle of dust emission and near-surface wind speed indicates that NLLJs play a role in dust emission. Using the automated NLLJ detection algorithm developed by Fiedler et al. (2013) allows a more detailed analysis. The NLLJ occurrence frequency is defined as the percentage of nights showing a NLLJ. In the annual and spatial mean, the NLLJ occurrence frequency from HadGEM2-ES is $27 \%$, remarkably close to $29 \%$ found in ERA-Interim for 1980-2009. Figure 6 shows the spatial distribution of the occurrence frequency of NLLJs in HadGEM2-ES, in ERAInterim and the difference between both climatologies. While both models show NLLJ occurrence maxima with frequencies exceeding $30 \%$ along a distinct band over the southern parts of the Sahara, NLLJ occurrence maxima in HadGEM2-ES are shifted southwards and appear in a band (a) HadGEM2-ES

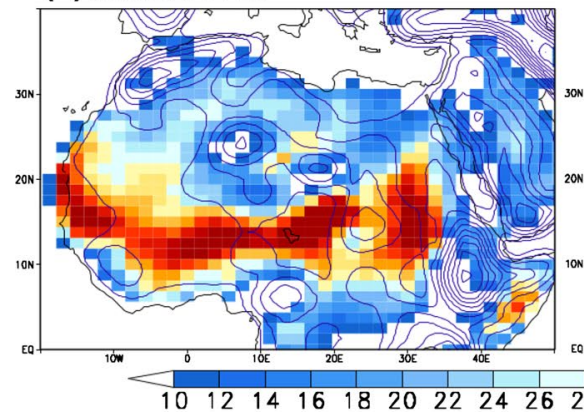

(b) ERA-Interim

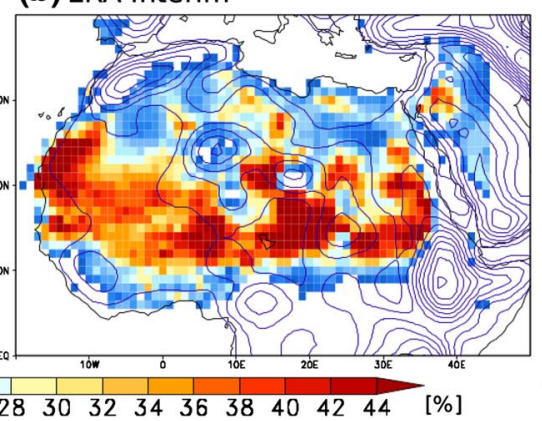

(c) HadGEM2-ES - ERA-Interim

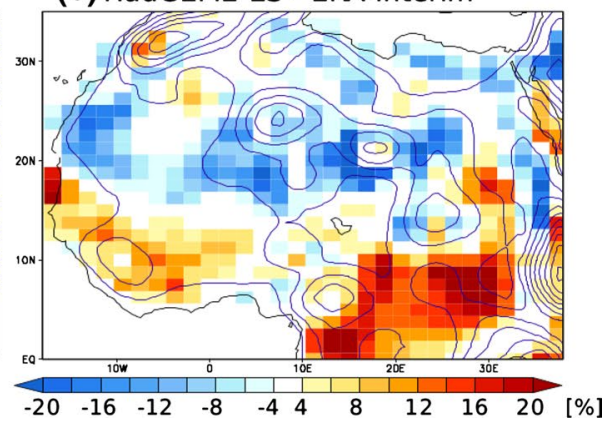

Fig. 6 Annual mean climatology of nocturnal low-level jets. Annual mean NLLJ occurrence frequency for (a) HadGEM2-ES, (b) ERA-Interim and (c) absolute difference of NLLJ frequency from
HadGEM2-ES relative to ERA-Interim for 1980-2009. Blue contours show the terrain height in steps of $200 \mathrm{~m}$ 
that is narrower over the West. Computing the difference between both models shows that NLLJs in HadGEM2-ES occur up to 12 and $20 \%$ more frequently in southern West Africa and central Africa, respectively. The difference in the latter region, however, has no implication for dust emission because of the lack of dust sources near the equator.
In contrast to these larger numbers of NLLJs, nights with NLLJs in the center, north and west of North Africa are up to $20 \%$ less frequent.

The seasonal distributions are investigated to identify the time of largest differences. Figure 7 shows the seasonal distribution of NLLJ occurrence frequencies in HadGEM2-ES
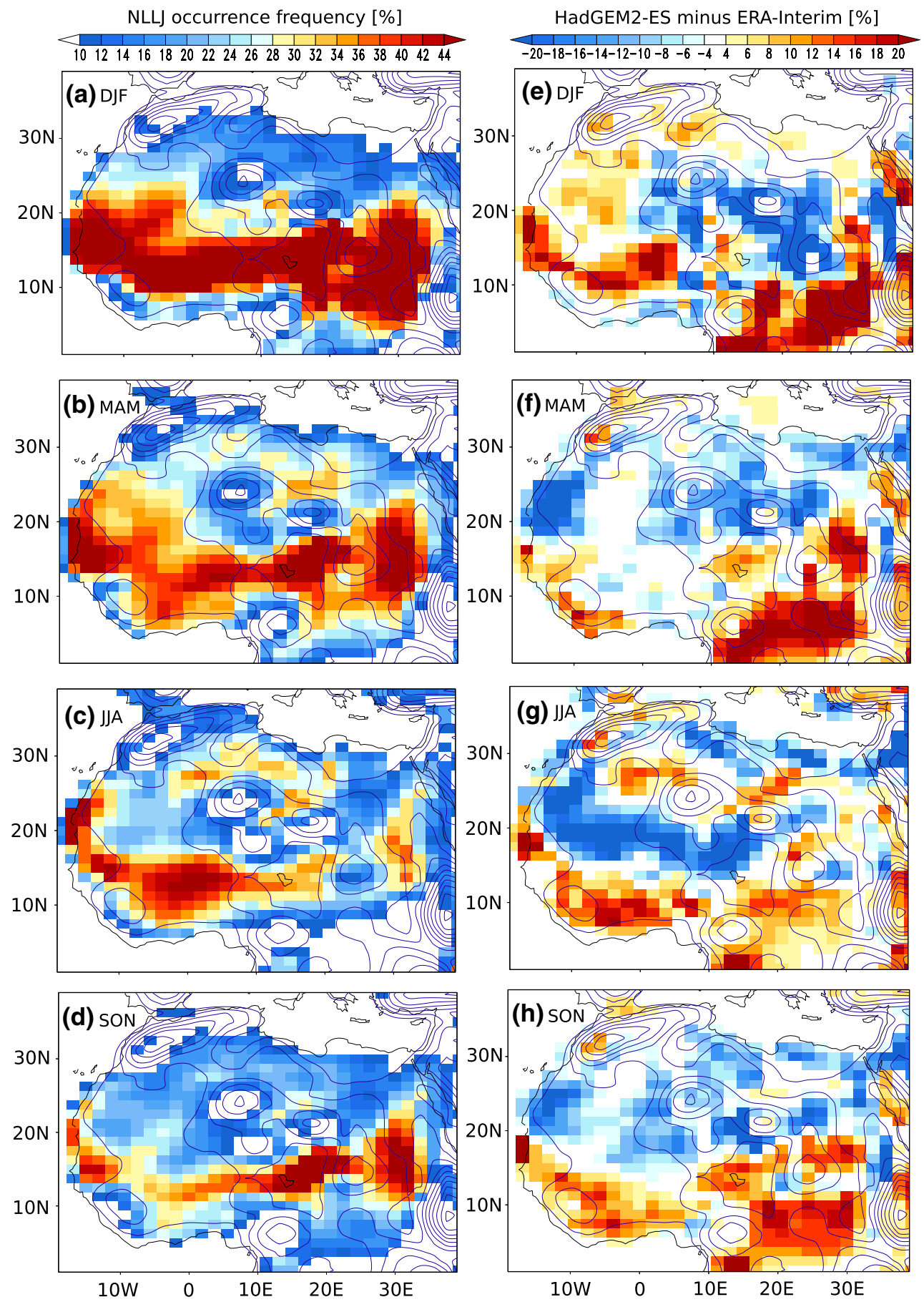

Fig. 7 Seasonal mean climatology of nocturnal low-level jets. Seasonal mean NLLJ occurrence frequency for (left, a-d) HadGEM2ES and (right, e-h) absolute difference of NLLJ frequency for

HadGEM2-ES minus ERA-Interim for 1980-2009. Blue contours show the terrain height in steps of $200 \mathrm{~m}$ 
and the differences between HadGEM2-ES compared to ERA-Interim. During winter NLLJs occur more frequently over West Africa in HadGEM2-ES with typical differences of 4-20\% (Fig. 7a, e). At the same time, areas in the central Sahara are characterized by fewer events. In spring, an underestimation compared to ERA-Interim is more widespread, when the west coast and northern parts of Africa have fewer events by -8 to $-20 \%$, but the Bodélé Depression shows more NLLJs by up to $10 \%$ (Fig. 7b, f).

Summertime West Africa shows fewer NLLJs in HadGEM2-ES, while areas further south have larger numbers of NLLJ nights (Fig. 7c, g). More NLLJs are also detected over southern areas of Algeria and Libya in summer. At the same time fewer events are detected along the northern coast of Libya. This pattern strongly suggests a southward displacement of NLLJ maxima along the margins of the Saharan heat low. The shift of the heat low and, therefore, the NLLJ maxima, may be connected to the southward displaced monsoon in HadGEM2-ES. The pattern of more NLLJs in the south and less in the north of West Africa is also found in autumn, but now accompanied by more NLLJ nights in the Bodélé Depression (Fig. 7d, h).

\subsubsection{Associated dust emission}

The importance of NLLJs for dust emission in T-H2ES-O is measured by quantifying the dust emission amount associated with NLLJs, i.e. dust emitted during NLLJ events as in Fiedler et al. (2013). Figure 8 shows the fraction of dust emission in T-H2ES-O that coincide with NLLJs in HadGEM2-ES and the difference to T-EI-O. Particularly in winter $25-50 \%$ of the dust emission is associated with NLLJs south of $25^{\circ} \mathrm{N}$ in T-H2ES-O (Fig. 8a). Here, T-H2ES-O has larger fractions in western areas compared to T-EI-O on the order of $30 \%$ (Fig. 8a). In the Bodélé Depression around $50 \%$ of the emission is associated with NLLJs in T-H2ES-O, which is of the same order of magnitude as in T-EI-O. The spatial distribution in spring is similar, but shows NLLJ contributions exceeding $50 \%$ over larger areas in the south (Fig. 8b). Particularly, western areas south of $20^{\circ} \mathrm{N}$ have again larger fractions by more than $30 \%$ in T-H2ES-O compared to T-EI-O. Dust emission associated with NLLJs increases to values larger than $25 \%$ over most of the north in spring which is at least $10 \%$ larger than in T-EI-O. The spatial distribution in summer and autumn is similar to spring (Fig. 8c, d). In Libya, $40 \%$ of the dust emission is associated with NLLJs during summer which is typically $20 \%$ larger than in T-EIO. Characteristic amounts of dust emission coinciding with NLLJs over parts of West Africa in summer and autumn are $30 \%$, which is in some areas larger by $10-20 \%$ compared to T-EI-O.

In summary, NLLJs occur more frequently in HadGEM2-ES than in ERA-Interim in southern parts of West Africa throughout the year and in the area of the Bodélé Depression in spring and autumn. West African
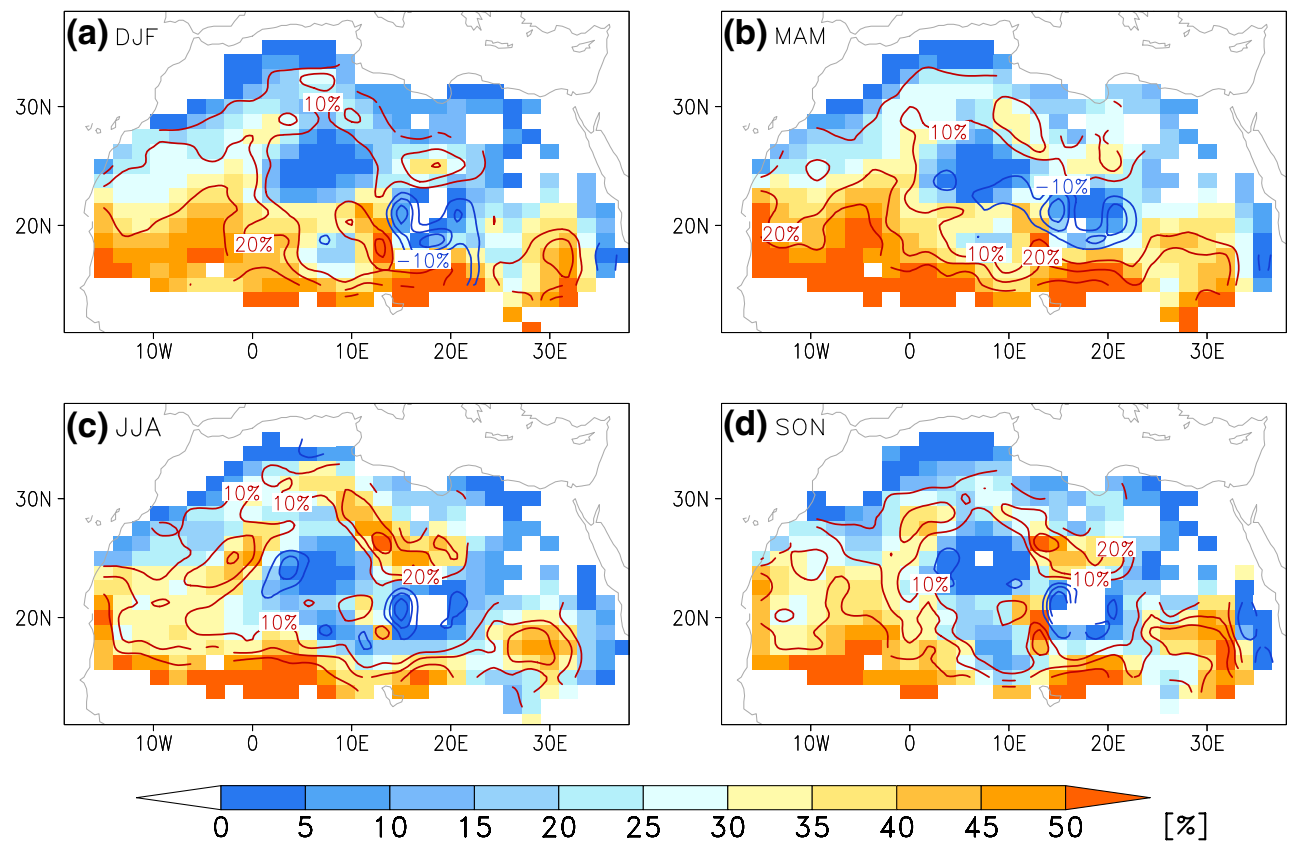

Fig. 8 Fraction of dust emission associated with NLLJs. Seasonal mean (shaded) fraction of dust emission from T-H2ES-O associated with NLLJs and (contours) absolute difference in fraction associated with
NLLJ compared to T-EI-O for (a) December-February, (b) March-May, (c) June-August and (d) September-November 1980-2009 

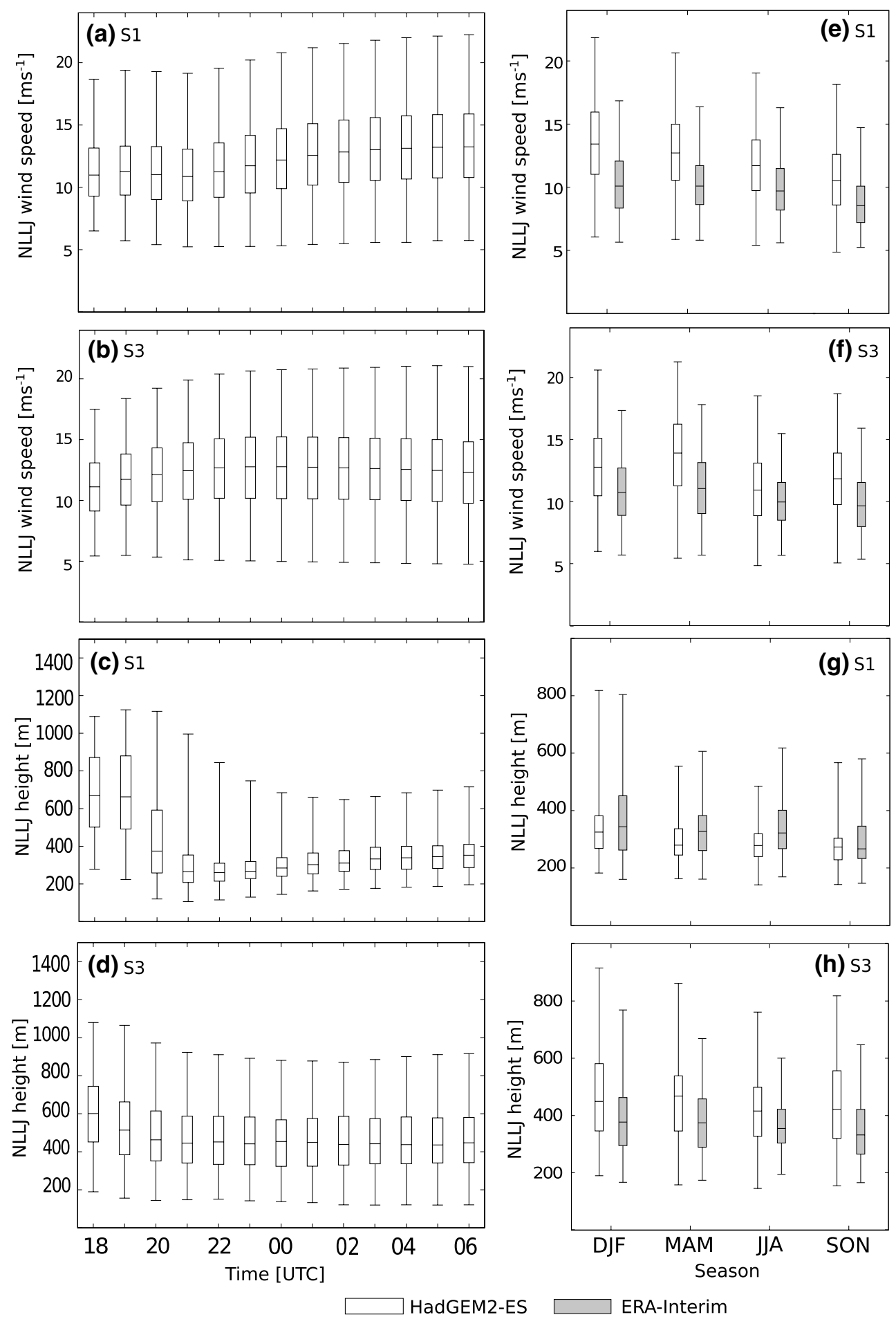

Fig. 9 NLLJ characteristics. (a-d, left) Temporal development of hourly box-and-whisker plots showing (from top to bottom) the 99-, 75-, 50-, 25- and $1 \%$-percentiles of the NLLJ core wind speed spatially averaged for sub-domain (a) S1 and (b) S3 and the NLLJ core height spatially averaged for (c) S1 and (d) S3 based on HadGEM2-
ES 1989-2009 and (e-h, right) box-and-whisker plots of the NLLJ core wind speed spatially averaged for sub-domain (a) S1 and (b) S3 and the NLLJ core height spatially averaged for (c) S1 and (d) S3 at 00 UTC based on HadGEM2-ES and ERA-Interim 
areas, particularly south of $20^{\circ} \mathrm{N}$, have a larger fraction of dust emission associated with NLLJs in HadGEM2-ES. The more frequent number of NLLJs in HadGEM2-ES and the large contributions of NLLJs to dust emission in certain regions of North Africa support the hypothesis that differences in the NLLJ frequency and their characteristics are a cause of larger dust emission during the mid-morning in T-H2ES-O. It is interesting to understand whether this is an effect of more frequent NLLJ formation only or whether the wind speed and height of the NLLJ plays a role. The NLLJ characteristics are therefore analyzed for the two key regions next.

\subsubsection{NLLJ characteristics}

The speed and height of NLLJs are important for the downward mixing of momentum to the surface. These variables are investigated for a thorough evaluation of the NLLJ in HadGEM2-ES for the two key regions S1 and S3 covering parts of West Africa and wide areas around the Bodélé Depression, respectively. Figure 9 shows the NLLJ core wind speed and height in HadGEM2-ES for these subdomains. In S1, the median wind speed in the NLLJ core is around $11 \mathrm{~ms}^{-1}$ at the beginning of the night (Fig. 9a). Between 21 UTC and 03 UTC the median core wind speed of NLLJs increases to $13 \mathrm{~ms}^{-1}$ and persists at this value until 06 UTC. As in ERA-Interim (Fiedler et al. 2013), a nocturnal or near-morning wind speed maximum in the NLLJ core does not exist, which is consistent with artificially increased vertical mixing in both models (Brown et al. 2006, 2008; Sandu et al. 2013). The median core wind speed in HadGEM2-ES, however, is $2 \mathrm{~ms}^{-1}$ larger compared to ERA-Interim shown in Fiedler et al. (2013), probably at least partly related to a weaker enhancement of vertical mixing in HadGEM2-ES (Sect. 2, Brown et al. 2008). The upper end of the wind speed distribution in the core of NLLJs has values of up to $23 \mathrm{~ms}^{-1}$, which is higher than in ERA-Interim with $17 \mathrm{~ms}^{-1}$. This upper end of the distribution is particularly important for dust emission due to the non-linear dependency on the wind speed. The distribution of core wind speeds in S3 shows an earlier increase of the median wind speed from $11 \mathrm{~ms}^{-1}$ at 18 UTC to $12.5 \mathrm{~ms}^{-1}$ at 22 UTC (Fig. 9b). Here the development of the nocturnal boundary layer is more advanced at 18 UTC, which corresponds to 19 local time (LT). In contrast, 18 UTC in the west is 17 LT which is too early for NLLJ formation over wide areas. The highest value of the $99 \%$-percentile in the early morning is in S3 $22 \mathrm{~ms}^{-1}$, therefore slightly lower than in the western sub-domain, but substantially larger than in ERA-Interim with $18 \mathrm{~ms}^{-1}$ shown in Fiedler et al. (2013).

While the NLLJ wind speed is shifted to higher values in HadGEM2-ES, the NLLJ core height is comparable between both models in S1 (Fig. 9c). After a sharp decrease of NLLJ core heights in the first evening hours, HadGEM2ES has median NLLJ heights around $250 \mathrm{~m}$ increasing to $350 \mathrm{~m}$ for $03-06$ UTC. The height during the morning is of the same order of magnitude as the ERA-Interim longterm median for this region. The difference in the median NLLJ height in S3 with typically $450 \mathrm{~m}$ in HadGEM2-ES and $380 \mathrm{~m}$ in ERA-Interim (Fig. 9d) is too small for being resolved by HadGEM2-ES with levels at 250, 410 and $610 \mathrm{~m}$ a.g.l. It is interesting that the NLLJ height is not as sharply decreasing in the early evening in S3 as in S1. This difference is likely caused by a more advanced nocturnal development at 18 UTC (19 LT) in S3 located in the east of the continent.

The nocturnal development suggests substantial differences of the NLLJ wind speed between ERA-Interim and HadGEM2-ES. Figure 9e-h show the comparison of the NLLJ wind speed and height seasonally averaged for S1 and S3. The largest median values of NLLJs in S1 occur in winter with $13 \mathrm{~ms}^{-1}$ at $320 \mathrm{~m}$ and gradually decrease in the following seasons to $11 \mathrm{~ms}^{-1}$ at $270 \mathrm{~m}$ in autumn. Compared to ERA-Interim, these median wind speeds are larger by $2-3 \mathrm{~ms}^{-1}$ while the $99 \%$-percentiles of the NLLJ wind speed are even larger by up to $5 \mathrm{~ms}^{-1}$. S3 shows similarly large NLLJ wind speeds (Fig. 9f) at similar altitudes of the NLLJ core (Fig. 9h). Reasons for larger NLLJ wind speeds at similar altitudes in HadGEM2-ES may be due to model differences in the representation of synoptic-scale conditions and the stability in the nocturnal boundary layer which are investigated in the next two sections.

\subsection{Synoptic-scale conditions}

The synoptic-scale conditions are compared by analyzing monthly mean geopotential heights. The $925 \mathrm{hPa}$ level is chosen as a representative height for the core of NLLJs in HadGEM2-ES. Figure 10a-d show the seasonal climatology of the geopotential height at this level at 00 UTC, the time of day when the re-analysis spread is smallest (not shown) and when NLLJs occur. Winter and spring are characterized by a mean ridge extending from the Azores towards northern Africa and a mean heat trough in the south. The horizontal pressure gradient across the continent is larger in HadGEM2-ES during these months and particularly strong in winter (Fig. 10a). These differences between HadGEM2-ES and ERA-Interim are an order of magnitude larger than the difference in the geopotential height at $925 \mathrm{hPa}$ in winter between ERA-Interim, MERRA, CFSR and NCEP/NCAR re-analysis data for 1980-2001 (not shown). The larger horizontal gradient in the geopotential height at $925 \mathrm{hPa}$ in HadGEM2-ES affects the geostrophic wind which is the first-order driver of the actual wind speed. 


\section{Geopotential height [gpdm]}

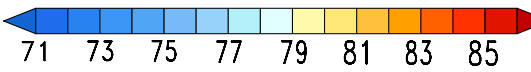

(a) DJF

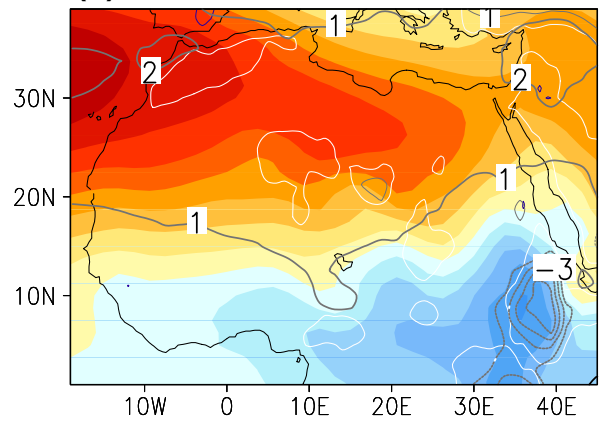

(b) MAM

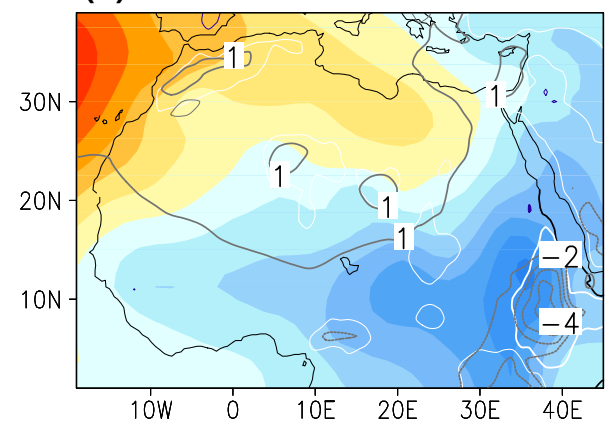

(c) JJA

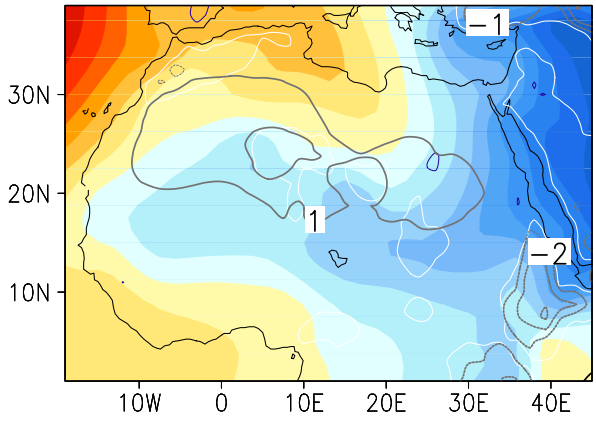

(d) SON

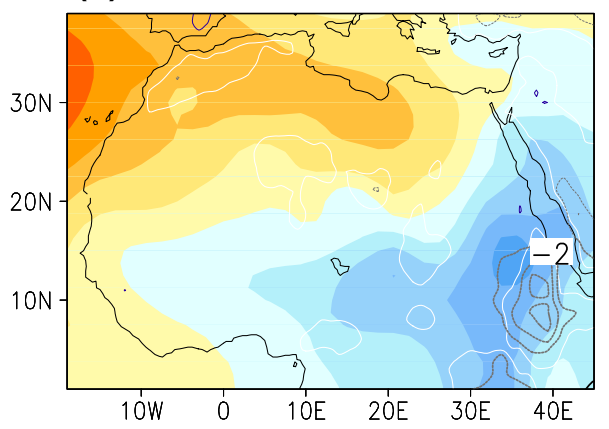

Fig. 10 Climatology of geopotential height and geostrophic wind at $925 \mathrm{hPa}$ at $00 \mathrm{UTC}$. Seasonal mean of (a-d, left) geopotential height and (e-h, right) geostrophic wind speed at $925 \mathrm{hPa}$ from (shaded) HadGEM2-ES and (grey contours) difference of HadGEM2-ES

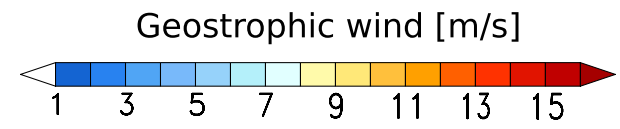

(e) DJF

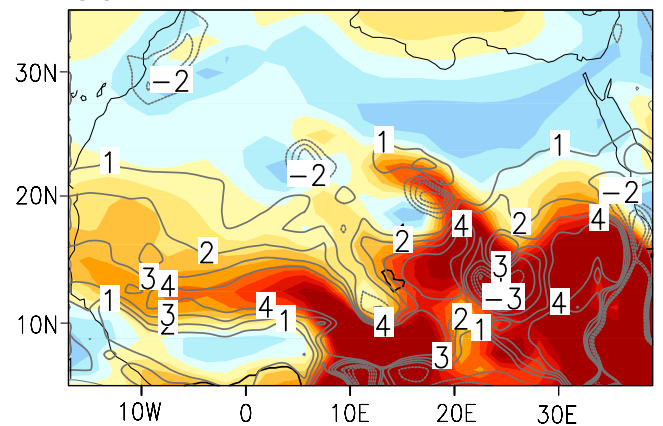

(f) MAM

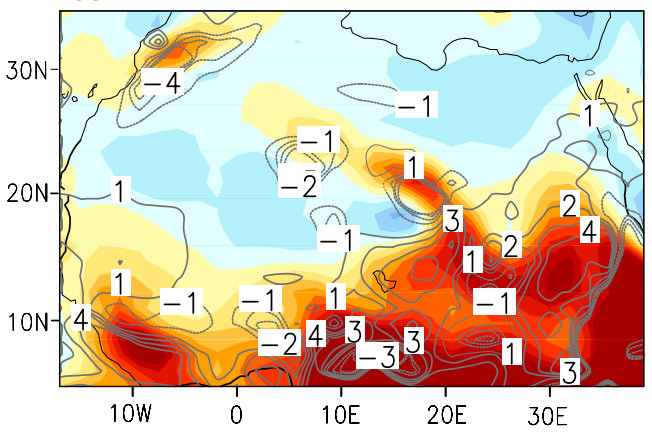

(g) JJA

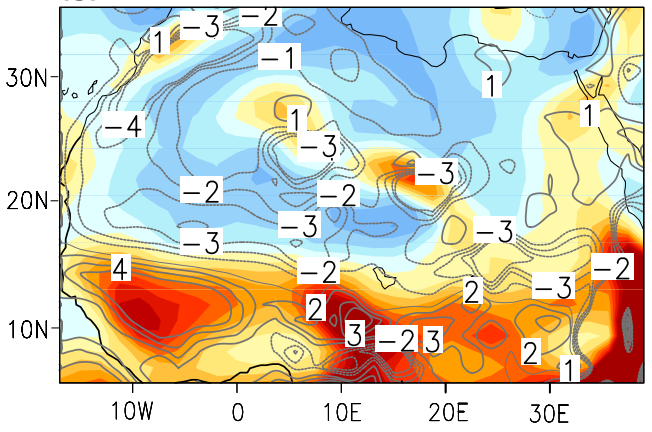

(h) SON

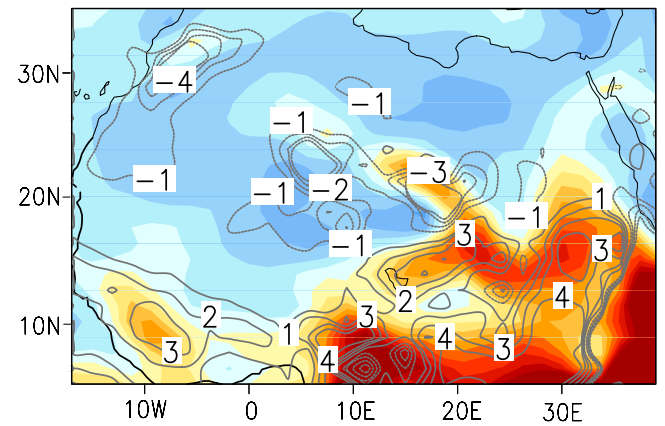

minus ERA-Interim for 1989-2009. Note that $925 \mathrm{hPa}$ lies below the surface in mountainous terrain causing differences there. Mountains are indicated by the $700 \mathrm{~m}$-isohypse (a-d, white contour) 
In order to quantify the contribution from differences in the synoptic-scale conditions between both models, the geostrophic wind at $925 \mathrm{hPa}\left|\mathbf{v}_{\mathbf{g}}\right|=\sqrt{u_{g}^{2}+v_{g}^{2}}$ is calculated from the geopotential height $\phi$ and the latitude-dependent Coriolis parameter $f$ following (e.g. Stull 1988):

$u_{g}=\frac{1}{f} \frac{\Delta \phi}{\Delta y}$

$v_{g}=-\frac{1}{f} \frac{\Delta \phi}{\Delta x}$.

Figure 10e-h shows the seasonal mean geostrophic wind at $925 \mathrm{hPa}$. At that level $\left|\mathbf{v}_{\mathbf{g}}\right|$ is larger in HadGEM2-ES by up to $4 \mathrm{~ms}^{-1}$ over all southern sub-domains during winter (Fig. 10e). Similarly, larger geostrophic winds are found during spring, but the spatial extent of areas with larger $\left|\mathbf{v g}_{\mathbf{g}}\right|$ in HadGEM2-ES is smaller. Since $\left|\mathbf{v}_{\mathbf{g}}\right|$ is a strong control of the NLLJ wind speed, their larger values in HadGEM2ES in S1 and S3 during winter and spring are likely causally related. The conditions at 12 UTC show similar results for these months (not shown). The stronger geostrophic Harmattan winds at that time, consistent with a larger gradient in the geopotential height, likely cause the stronger $10 \mathrm{~m}$-wind speeds and dust emission during midday in S1 and $\mathrm{S} 3$ during winter and spring.

May to September is dominated by the establishment of the heat low over West Africa (Fig. 10b-d). The heat low is shifted southwards in HadGEM2-ES which is connected to a southward displaced West African monsoon system. Along with the shift of the heat low, the position of NLLJ occurrence maxima along the margins change. At the same time smaller geostrophic winds are found for HadGEM2-ES over most areas in the north and in the central Sahara, contrary to areas along the southern margins of the heat low with geostrophic wind speeds larger by up to $4 \mathrm{~ms}^{-1}$ (Fig. 10g). Here, the sensitivity test H2ES-C shows a clear increase of the near-surface wind speed which coincides with larger dust emission compared to H2ES-A (not shown). This result suggests that the vegetation dieback has a positive feedback on dust emission in H2ES-I through: (1) the increased bare soil fraction resulting in more potential dust sources and (2) stronger winds at the surface in agreement with Martin and Levine (2012). The larger geostrophic winds by up to $4 m s^{-1}$ over this area suggest that the synoptic-scale dynamics are more important than a reduction in the surface roughness associated with the vegetation die-back. Smaller values of $\left|\mathbf{v}_{\mathbf{g}}\right|$ over most of S1 are not consistent with the larger NLLJ wind speeds in summer, so it is likely that mechanisms other than the synoptic-scale conditions dominate here. Similarly, S3 has not as large a model difference in $\left|\mathbf{v}_{\mathbf{g}}\right|$ during summer as earlier in the year, so again other mechanisms are likely to contribute more to strong NLLJs.
From October onwards, the heat low retreats to the southeast while the ridge over the north strengthens again (Fig. 10d). These conditions are similarly simulated by HadGEM2-ES and ERA-Interim forecasts. Since the mean pressure gradient over northwest Africa is not affected as much as at the beginning of the year, the geostrophic wind speed differences are smaller (Fig. 10h). Only areas close to the wintertime heat low in the east and in the Bodélé Depression show larger geostrophic winds in HadGEM2ES. Over the West, weaker boundary layer mixing under stable stratification in HadGEM2-ES (Brown et al. 2008) may contribute more to the larger NLLJ wind speeds during summer and autumn, and this is analyzed next.

\subsection{Stability associated with NLLJs}

In addition to the geostrophic wind, the strength of NLLJs is determined by the low-level stability and the potential momentum loss at the NLLJ level due to vertical mixing. Figure 11 shows the seasonally averaged diurnal cycle of stability characteristics associated with NLLJs for the subdomains S1 and S3, respectively. The $1 \%$-percentile of the vertical gradient of the virtual-potential temperature as a measure of the minimum stability below the NLLJ core is similar in both models due to the applied threshold for NLLJ detection. However, also the median is often similar in both models, particularly in S1 during spring from 21 to 06 UTC (Fig. 11b). A small tendency towards larger nocturnal stability below the NLLJ core in HadGEM2ES is found for S1 during summer and autumn (Fig. 11c, d) and towards less stable conditions for S3 during winter and spring (Fig. 11e, f). The larger stability suggests a stronger frictional decoupling and therefore the possibility of developing stronger NLLJs despite the smaller geostrophic winds in this region and season. Weaker stability would imply weaker winds in the NLLJ if all other conditions are similar. However, larger NLLJ wind speeds are found for HadGEM2-ES in S3 at the beginning of the year. In this case the synoptic-scale conditions cause larger geostrophic winds that are particularly favorable for stronger NLLJs. It is interesting that both regions show larger stability in HadGEM2-ES during winter in the early morning. This implies that NLLJ may survive for a longer time in HadGEM2-ES before being eroded by turbulent mixing.

Vertical wind shear below the NLLJ level is taken into account by analyzing the gradient Richardson number $R i$, which describes the onset of turbulence and is defined in Sect. 2. Both sub-domains show substantially larger values of the median of $R i$ in ERA-Interim throughout the year (Fig. 11). Since the differences in the stability below NLLJs are relatively small, the smaller $R i$ numbers in HadGEM2-ES give a strong indication that the vertical 
(a) DJF Sub-domain S1

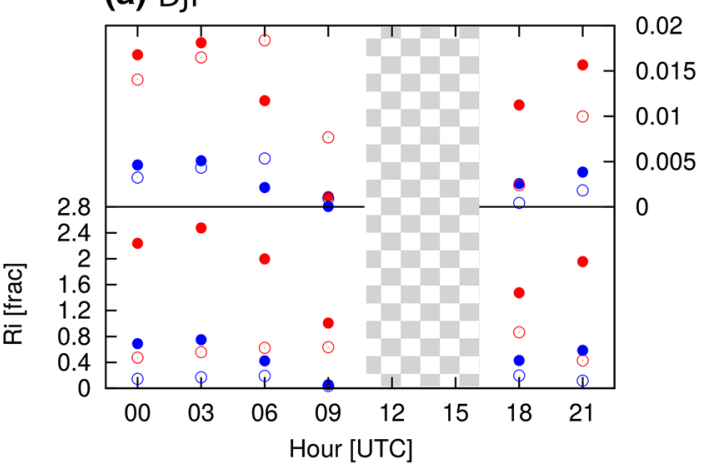

(b) MAM

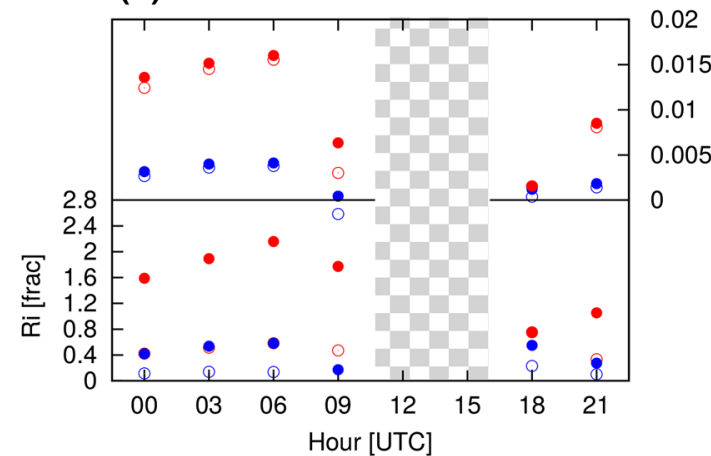

(c) $\mathrm{JJA}$

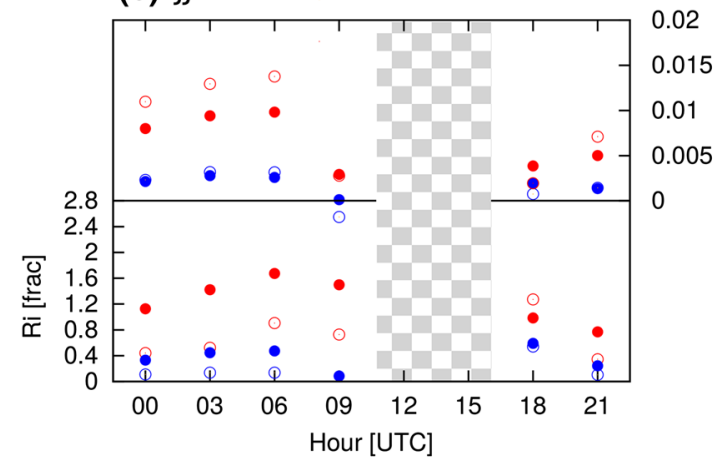

(d) SON

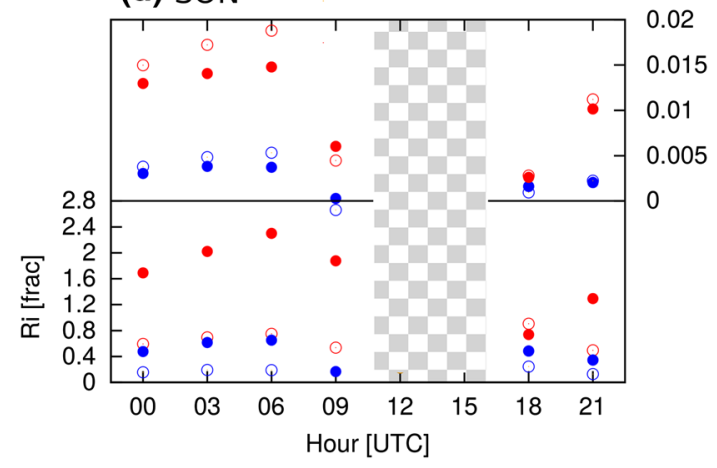

OH2ES $50 \%$

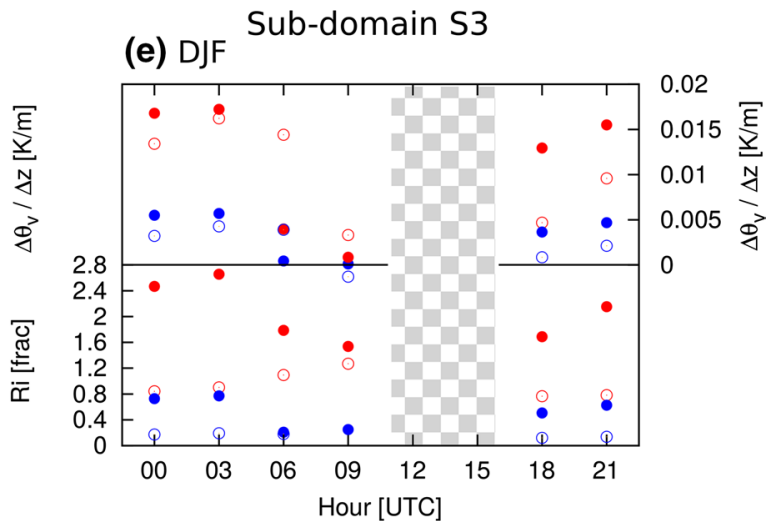

(f) MAM

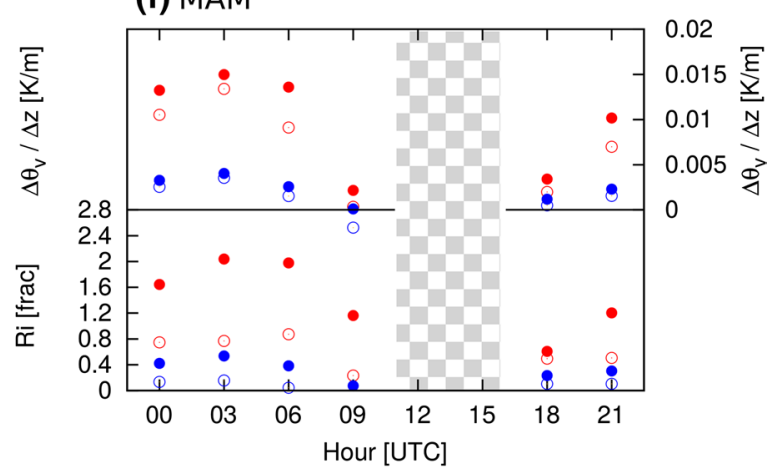

(g) JJA

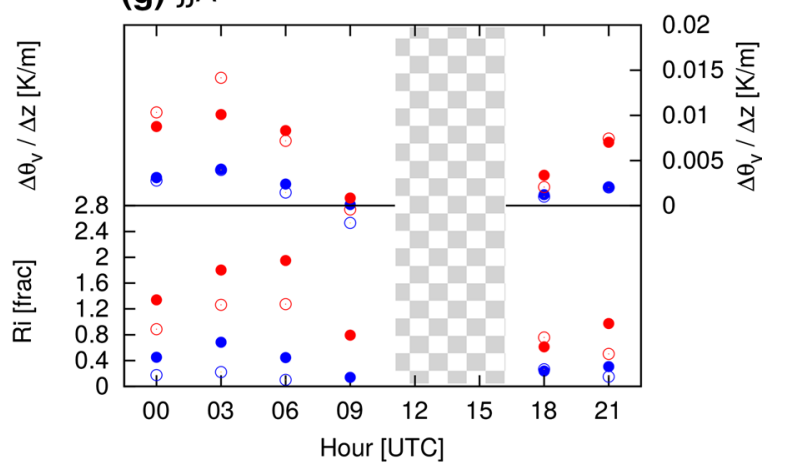

(h) SON

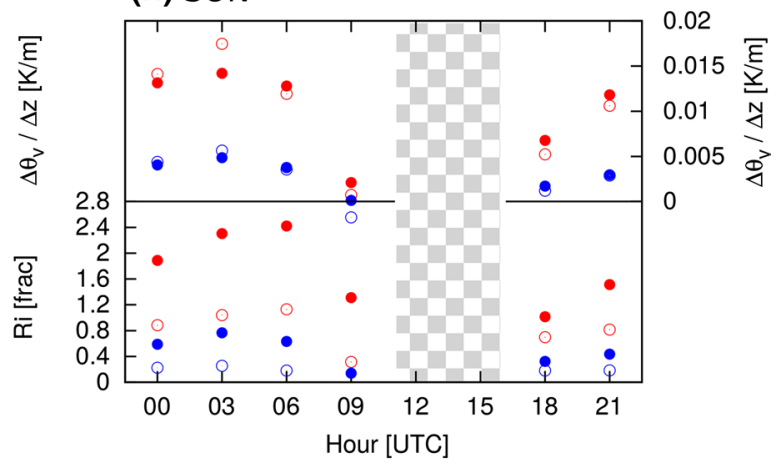

El $50 \% \bigcirc \mathrm{O} 2 \mathrm{ES} 1 \% \bigcirc \mathrm{EI} 1 \%$
Fig. 11 Seasonal mean diurnal cycle of stability characteristics associated with NLLJs. Shown are the mean diurnal cycles for $(\mathbf{a}, \mathbf{e})$ DecemberFebruary, (b, f) March-May, (c, g) June-August and (d, h) SeptemberNovember for 1980-2009 of the (blue) $1 \%$ and (red) $50 \%$ percentiles for (top) the vertical gradient of the virtual potential temperature $\Delta \theta_{v} / \Delta \mathrm{z}$ and (bottom) the gradient Richardson number Ri spatially averaged for NLLJ events in sub-domain (a-d, left) S1 and (e-h, right) S3 for (empty circles) HadGEM2-ES and (filled circles) ERA-Interim. Values are calculated between the NLLJ core and the lowest model level. Sample sizes at 12 and 15 UTC are too small for a statistical analysis and therefore not shown 
wind shear below NLLJs is much larger consistent with stronger NLLJs at similar heights. Based on S1 in spring, when the stability in both models agree particularly well, the vertical wind shear between the median NLLJ height and the ground is $30 \%$ larger in HadGEM2-ES $\left(0.045 \mathrm{~s}^{-1}\right)$ than in ERA-Interim $\left(0.031 \mathrm{~s}^{-1}\right)$.

The $1 \%$-percentile of $R i$ in HadGEM2-ES is mostly lower than in ERA-Interim suggesting that HadGEM2-ES is more prone to nocturnal mixing during NLLJ events. As in ERA-Interim, the vertical exchange coefficient for momentum in HadGEM2-ES is artificially increased (Brown et al. 2006, 2008; Sandu et al. 2013). This leads to an overestimation of vertical momentum mixing, weakening the NLLJ and increasing the near surface winds at night (Fiedler et al. 2013; Sandu et al. 2013). These winds can also be strong enough for nocturnal dust emission in T-H2ES-O (compare Fig. 5). As a result, the NLLJ accelerates to a certain speed and remains at that wind speed level during the night similar to ERA-Interim. The NLLJ core wind speed, however, is larger in HadGEM2-ES likely due to the smaller enhancement of the vertical mixing than in ERA-Interim (Brown et al. 2008; Sandu et al. 2013). This contributes to stronger NLLJs in HadGEM2-ES independent of the geostrophic wind speed, but the NLLJ wind is expected to be larger where the geostrophic wind is also stronger.

\subsection{Discussion}

The Earth system model HadGEM2-ES is analyzed regarding the simulation of dust emissions and NLLJs as driving mechanism. Dust emissions are calculated offline with the model by Tegen et al. (2002) which is driven with 10m-wind speeds from HadGEM2-ES (T-H2ES-O) and ERA-Interim forecasts (T-EI-O) for investigating the isolated effect of winds on dust emission. The level of the dust emission amount from the interactive emission scheme in HadGEM2-ES (H2ES-I) is closer to the offline version T-H2ES-O than T-H2ES-O to T-EI-O, suggesting that the impact of the wind speed is larger than the choice of the dust emission parametrization scheme. Differences in their spatial distribution of dust emission are apparent over the Sahel where H2ES-I produces large amounts compared to T-H2ES-O with virtually no events. Emission is here enabled by a vegetation die-back in the dynamic vegetation parametrization of HadGEM2-ES due to a rainfall deficit (Collins et al. 2011; Martin and Levine 2012). Simultaneously larger near-surface wind speeds over this area coincide with larger geostrophic winds pointing to the importance of the synoptic-scale conditions. The results of this study lead to the general question whether increased model complexity of an Earth system model adds value to the estimate of North African dust emission. Although this study is undertaken for HadGEM2-ES, other CMIP5 models may show similar uncertainties. For instance, Evan et al. (2014) suggest that CMIP5 models in general show differences in the dust aerosol life cycle compared to observations. The approach of isolating processes affecting emission applied in this study could help to identify systematic behavior for further improvements of those models.

The results highlight that T-H2ES-O has substantially larger dust emission over North Africa compared to T-EI$\mathrm{O}$, particularly in winter and spring. These differences of the emitted dust amount are pronounced in the West African sub-domain and the Bodélé Depression where stronger winds are simulated compared to ERA-Interim. The origin of these larger wind speeds and dust emissions are addressed by evaluating the NLLJ frequency, their characteristics, the atmospheric stability and the synoptic-scale conditions. The key findings of the evaluation from the two key regions, captured by the sub-domains S1 and S3, are discussed in the following.

\subsubsection{Sub-domain $S 1$}

Sub-domain S1, situated over parts of West Africa, shows clear evidence for larger dust emission in T-H2ES-O in winter due to a more frequent formation of NLLJs accompanied by stronger wind speeds in their core. The mechanism is schematically depicted in Fig. 12 and the key differences between HadGEM2-ES and ERA-Interim are summarized in Table 3. The results for winter underline that the horizontal gradient of the geopotential height at $925 \mathrm{hPa}$, a typical height for NLLJs, is substantially larger in HadGEM2-ES due to a stronger ridge stretching from the Azores High to northern Africa, which is an order of magnitude larger than the uncertainty in the geopotential height from four re-analysis data sets (not shown). Similarly, an overestimation and shift of the Azores High have been identified in the global climate model ECHAM4 (Timmreck and Schulz 2004). The geostrophic wind aids the formation of stronger NLLJs and also stronger Harmattan winds during the day. The stronger geostrophic winds are likely the most important reason for larger NLLJ wind speeds in this region and season. In addition to the geostrophic winds, low-level static stability can be a contributing factor to the NLLJ strength and associated dust emission. The static stability agrees well between HadGEM2-ES and ERA-Interim. At the same time the vertical wind shear is larger in HadGEM2-ES due to the stronger wind speeds in the NLLJ core. As result, the gradient Richardson numbers are smaller and more often below the critical value for vertical mixing. These mixing events of NLLJ momentum likely contribute to higher nocturnal 10m-wind speeds and dust emission in HadGEM2ES. The stronger geostrophic wind likely aids the acceleration of the wind in the NLLJ core after a nocturnal event 
Table 3 Summary of findings for sub-domain S1

\begin{tabular}{llllc}
\hline Differences in & Dec-Feb & Mar-May & Jun-Aug & Sep-Nov \\
\hline Dust emission $\left(\mathrm{gm}^{-2}\right)$ & $\mathbf{1 0}$ & $\mathbf{8}$ & 3 & 1 \\
Emission associated with NLLJs $(\%)$ & $\mathbf{2 0}$ to $\mathbf{3 0}$ & $\mathbf{2 0}$ to 30 & 10 to 20 & $\mathbf{2 0}$ to 30 \\
NLLJ event frequency (\%) & 0 to 20 & 20 to 20 & 20 to 20 & 20 to 20 \\
Median NLLJ wind speed $\left(\mathrm{ms}^{-1}\right)$ & $\mathbf{3}$ & 2 & 2 & 2 \\
99\%-percentile $\left(\mathrm{ms}^{-1}\right)$ & $\mathbf{5}$ & $\mathbf{4}$ & $\mathbf{3}$ & $\mathbf{4}$ \\
Median Ri (frac) & $\mathbf{1 . 5}$ & 1 & 0.5 & 1 \\
Geopotential height at $925 \mathrm{hPa}_{\text {Geostrophic wind speed }\left(\mathrm{ms}^{-1}\right)}$ & Stronger High & Stronger High & Shifted Low & Shifted Low \\
\hline
\end{tabular}

Modest (largest) overestimation of meteorological parameters of HadGEM2-ES compared against ERAInterim and dust emission from T-H2ES-O against T-EI-O highlighted in italics (bold)

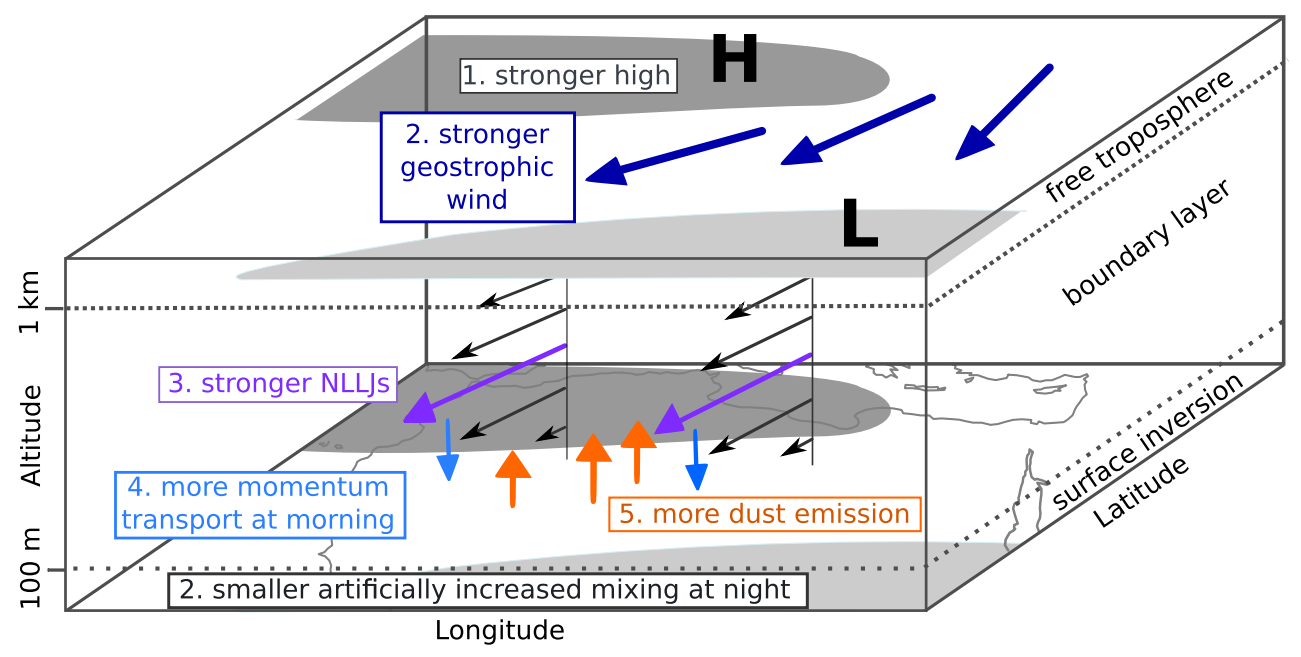

Fig. 12 Schematic summary of key differences of HadGEM2-ES compared to ERA-Interim for December to May

of vertical momentum mixing. In consequence, the NLLJ core wind speeds remain strong leading to larger dust emission at the following morning compared to T-EI-O.

Conditions in spring are similar regarding the dust emission associated with NLLJs, the NLLJ speed, the geopotential height and the geostrophic wind (Table 3). Regions with larger NLLJ frequencies in HadGEM2-ES, however, are limited to southwest Africa while the center shows little differences in NLLJ occurrence and areas along the coast show a reduction compared to ERA-Interim. The time of maximum emission and wind speed is also later at 12 UTC, suggesting that the downward mixing of momentum in the daytime boundary layer in spring is more important for producing the majority of dust emission than the stronger NLLJs. These winds are driven by the larger horizontal gradient in the geopotential height that is present throughout the day.

Summer is characterized by a shift in NLLJ occurrence maxima due to the more southern position of the Saharan heat low in HadGEM2-ES. The Sahel has a larger bare soil fraction in H2ES-C compared to H2ES-A that leads to more dust emission because of more potential dust sources and larger near-surface wind speeds. In T-H2ES-O, larger dust emission occurs over southern West Africa and a substantial fraction of this is associated with NLLJs (Table 3). NLLJs are stronger here like earlier in the year. Differences in the horizontal gradient of the geopotential height, however, are smaller in HadGEM2-ES than in ERA-Interim. The weaker artificial enhancement of the vertical mixing in the stable boundary layer in HadGEM2-ES compared to ERA-Interim (Brown et al. 2008; Sandu et al. 2013) can therefore have a larger net impact on the strength of NLLJs in summer. The spatial shift of NLLJs persists until September and vanishes with the retreat of the heat low from West Africa thereafter.

\subsubsection{Sub-domain S3}

The Bodélé Depression is one of the most active places for dust emission and is located in sub-domain $\mathrm{S} 3$, for which the findings are summarised in Table 4. Here, T-H2ES-O shows 
Table 4 As Table 3 but for subdomain S3

\begin{tabular}{|c|c|c|c|c|}
\hline Differences in & Dec-Feb & Mar-May & Jun-Aug & Sep-Nov \\
\hline Dust emission $\left(\mathrm{gm}^{-2}\right)$ & 10 & 10 & 1 & 2 \\
\hline Emission associated with NLLJs (\%) & 20 to 20 & 10 to 30 & 10 to 30 & 10 to 30 \\
\hline NLLJ event frequency $(\%)$ & 20 to 0 & 14 to 14 & 20 to 14 & 20 to 20 \\
\hline Median NLLJ wind speed $\left(\mathrm{ms}^{-1}\right)$ & 2 & 3 & 1 & 2 \\
\hline $99 \%$-percentile $\left(\mathrm{ms}^{-1}\right)$ & 3 & 3 & 3 & 3 \\
\hline Median Ri (frac) & 1.5 & 1 & 0.5 & 1 \\
\hline Geopotential height at $925 \mathrm{hPa}$ & Stronger High & Stronger High & Shifted Low & Shifted Low \\
\hline Geostrophic wind $\left(\mathrm{ms}^{-1}\right)$ & Up to 4 & Up to 4 & 1 to 1 & Up to 3 \\
\hline
\end{tabular}

larger dust emission compared to T-EI-O throughout the year, particularly in winter and spring when peak emissions at 09 UTC point to the importance of NLLJs. NLLJ core wind speeds are particularly large in both seasons linked to stronger geostrophic winds at $925 \mathrm{hPa}$ in HadGEM2-ES (Fig. 12). NLLJs, however, occur less frequently in winter compared to ERA-Interim. This result is surprising as winter is the time of year when the channeling of the prevailing north-easterly Harmattan winds cause favorable conditions for NLLJ formation (Washington and Todd 2005; Todd et al. 2008; Fiedler et al. 2013). Todd et al. (2008) provide observational evidence that a stronger synoptic-scale pressure gradient across the Bodélé Depression causes high wind speeds throughout the day while the NLLJ mechanism enhances the winds during the following morning. It is likely that the vertical wind shear below the larger geostrophic winds in HadGEM2-ES leads to so much vertical mixing that the formation of NLLJs is prevented in some nights.

From spring onwards, the NLLJ wind speed as well as the 09 UTC maximum in both dust emission and 10m-wind speed suggest that the NLLJ is important for dust emission. The geostrophic winds in HadGEM2-ES are larger during spring and autumn (Table 4), pointing to a substantial contribution from synoptic-scale conditions. While the stability below the NLLJ core is remarkably similar in both models for those seasons, the gradient Richardson number is smaller in HadGEM2-ES and points to more nocturnal mixing events (Table 4). Here, the larger geostrophic winds may again aid NLLJs to strengthen after the weakening effect of vertical momentum mixing during the night. The stronger geostrophic winds are likely the first-order driver of stronger NLLJs and associated dust emission. A contributing factor to stronger NLLJs is the weaker enhancement of mixing during stable stratification in HadGEM2-ES (e.g. Brown et al. 2008).

\subsubsection{Uncertainty}

ERA-Interim is used as a benchmark for assessing the Earth system model HadGEM2-ES. While ERA-Interim is the best estimate of the past state of the atmosphere (e.g. Decker et al. 2012), the largest NLLJ winds are likely underestimated in ERA-Interim (Fiedler et al. 2013; Sandu et al. 2013). The spatial resolution and the physical parameterizations are sources for uncertainty which shall be briefly discussed based on existing studies.

While problems in modeling the stable atmospheric boundary layer (ABL) are known for decades, little progress has been made with regard to better simulating NLLJs (e.g. Holtslag et al. 2013). This is attributed to the physical parametrization of the ABL but also to weaknesses of other model components, e.g. the parametrizations of the soil, surface and radiation (e.g. Steeneveld et al. 2006, 2008). Higher spatial resolution in models can improve the representation of stable ABLs, but does not entirely solve the problem (e.g. Steeneveld et al. 2006; Svensson et al. 2011). By analyzing the regional model MM5 over the Bodélé Depression, Todd et al. (2008) indicate a small sensitivity of the NLLJ to the vertical resolution close to the surface. The horizontal resolution is important in complex terrain, but has a small effect on the NLLJ away from mountainous regions (Todd et al. 2008). Over West Africa, Schepanski et al. (2014) show with the regional model WRF and two state-of-the-art re-analysis products that changing the spatial resolution, ABL and surface-layer parametrization has overall smaller impacts on NLLJs than the initial and lateral boundary conditions. For another model nudged to ERA-Interim, Hourdin et al. (2014) indicate that improving the parametrization of dry convection in the daytime boundary layer positively affects the downward mixing of momentum from NLLJs during the following morning. In summer, NLLJs can be formed by aged cold pools above nocturnal near-surface temperature inversions (Heinold et al. 2013). This mechanism is poorly represented in both ERA-Interim and HadGEM2-ES, but their effect is rarely important in the dry season due to the dependence on convective downdrafts from deep moist convection. Although daytime near-surface winds in ERA-Interim are likely underestimated, ERA-Interim compares best against observations amongst state-of-the-art re-analysis (Decker et al. 2012; Largeron 2015). 


\section{Conclusion}

This work addresses the differences of dust-emitting winds between HadGEM2-ES and ERA-Interim data. Dust emission with HadGEM2-ES winds is five and seven times larger than in simulations with ERA-Interim and MERRA, respectively. Calculating dust emission with the same dust emission model driven by wind speeds from two atmospheric models allows an isolation of the effect of wind speed on dust emission and subsequently a systematic investigation of the meteorological processes causing these winds. The key findings from HadGEM2-ES in the CMIP5 model setup for 1980-2009 are:

1. The order of magnitude in the annual dust emission from HadGEM2-ES is closer to the offline dust emission calculation T-H2ES-O than T-H2ES-O to T-EI$\mathrm{O}$ which suggests that dust-emitting winds have a stronger impact on the emission amount than the emission parametrization. The spatial structure is influenced by the emission parametrization and highlights emission from the Sahel in HadGEM2-ES, which is enabled by a vegetation die-back in the Earth system model (Collins et al. 2011).

2. The downward mixing of NLLJ momentum is an important mechanism for dust emission in HadGEM2ES in agreement with findings for the ERA-Interim climatology (Fiedler et al. 2013). Annually and spatially averaged, the occurrence frequency of NLLJs is remarkably similar in the models, but the location of most frequent NLLJ formation shows distinct differences. For instance the NLLJ occurrence maxima at the margins of the summertime heat low are shifted to the south consistent with the southward displaced heat low in HadGEM2-ES.

3. The wind speeds in the NLLJ core and near the surface as well as the dust emission amount are substantially larger with HadGEM2-ES winds, despite the coarser spatial resolution. More detailed analysis of the underlying reasons points to combinations of a weaker artificial enhancement of the vertical mixing in stable boundary layers and larger geostrophic winds at $925 \mathrm{hPa}$, e.g. in winter caused by a stronger ridge over northern Africa in HadGEM2-ES. The stronger ridge exceeds the re-analysis uncertainty in the geopotential height at $925 \mathrm{hPa}$ by an order of magnitude.

4. Over parts of West Africa, the larger geostrophic winds in HadGEM2-ES are likely more important for the stronger NLLJs than the effect of stability from autumn to spring while the opposite is true during summer.

5. In the Bodélé Depression, the geostrophic winds during winter in HadGEM2-ES aid the occurrence of stronger NLLJs in agreement with observations from
Todd et al. (2008). However, the geostrophic wind may also become so large that the vertical wind shear prevents NLLJ formation in some nights.

While the parametrization of the stable boundary layer was expected as a possible source for differences in dust emission investigated here, the stronger ridge over North Africa during winter relative to ERA-Interim is surprising. Weaknesses in the parametrization of stable boundary layers are a known shortcoming of weather and climate models, further improvements of which are subject of ongoing research at the UK Met Office, ECMWF and elsewhere (e.g. Holtslag et al. 2013; Sandu et al. 2013). Future research on the reasons for differences in the strength of the ridge over northern Africa during winter between HadGEM2-ES and ERAInterim would be useful for future model development towards a better representation of meteorological processes. Since NLLJs and near-surface wind speeds depend on the pressure gradient force, any progress on representing the synoptic-scale conditions holds the potential to positively affect dust emission and therefore effects of dust aerosol in the Earth system.

The large wind speeds in combination with the vegetation die-back over the Sahel in the coupled Earth system model HadGEM2-ES leads to substantially more dust emission than calculated with re-analysis data. This result questions the added value of the increased complexity through a dynamic vegetation scheme for simulating dust emission. Also other CMIP5 models show little similarity of dust aerosol characteristics relative to satellite observations (Evan et al. 2014). The presented approach of isolating the effect of meteorological processes for dust emission is promising to help understanding and ultimately reducing the currently large uncertainty for dust aerosol in Earth system models.

Acknowledgments This work has been carried out as part of the Desert Storms project funded by the European Research Council under Grant Number 257543. G. M. Martin and S. Woodward were supported by the Joint UK DECC/Defra Met Office Hadley Centre Climate Program (GA01101). We acknowledge the usage of ERAInterim data provided by the European Centre for Medium-Range Weather Forecasts and HadGEM2-ES/-A data from the UK Met Office, the wind speed data of MERRA from the "Modeling and Assimilation Data and Information Services Center (MDISC)" and reanalysis data for the geopotential height from the website of "NOAAESRL Physical Sciences Division, Boulder Colorado" (http://www. esrl.noaa.gov/psd/).

Open Access This article is distributed under the terms of the Creative Commons Attribution 4.0 International License (http://creativecommons.org/licenses/by/4.0/), which permits unrestricted use, distribution, and reproduction in any medium, provided you give appropriate credit to the original author(s) and the source, provide a link to the Creative Commons license, and indicate if changes were made. 


\section{References}

Agust-Panareda A, Vasiljevic D, Beljaars A, Bock O, Guichard F, Nuret M, Garcia Mendez A, Andersson E, Bechtold P, Fink A, Hersbach H, Lafore JP, Ngamini JB, Parker DJ, Redelsperger JL, Tompkins AM (2009) Radiosonde humidity bias correction over the West African region for the special AMMA reanalysis at ECMWF. Q J R Meteorol Soc 135(640):595-617. doi:10.1002/qj.396

Bagnold RA (1941) The physics of blown sands and desert dunes. Methuen, New York

Bain CL, Parker DJ, Taylor CM, Kergoat L, Guichard F (2010) Observations of the nocturnal boundary layer associated with the West African Monsoon. Mon Weather Rev 138(8):3142-3156. doi:10. 1175/2010MWR3287.1

Banta R, Pichugina Y, Newsom R (2003) Relationship between lowlevel jet properties and turbulence kinetic energy in the nocturnal stable boundary layer. J Atmos Sci 60(20):2549-2555

Bellouin N, Rae J, Jones A, Johnson C, Haywood J, Boucher O (2011) Aerosol forcing in the Climate Model Intercomparison Project (CMIP5) simulations by HadGEM2-ES and the role of ammonium nitrate. J Geophys Res 116(D20):206. doi:10.1029/ 2011JD016074

Birch CE, Parker D, Marsham J, Copsey D, Garcia-Carreras L (2014) A seamless assessment of the role of convection in the water cycle of the West African Monsoon. J Geophys Res Atmos 119(6):2890-2912

Blackadar A (1957) Boundary layer wind maxima and their significance for the growth of nocturnal inversions. Bull Am Meteorol Soc 83:283-290

Boucher O, Randall D, Artaxo P, Bretherton C, Feingold G, Forster P, Kerminen VM, Kondo Y, Liao H, Lohmann U, Rasch P, Satheesh S, Sherwood S, Stevens B, Zhang X (2013) Clouds and Aerosols. In: Climate change 2013: the physical science basis. Contribution of working group I to the fifth assessment report of the intergovernmental panel on climate change. Cambridge University Press, Cambridge

Brown A, Beare R, Edwards J, Lock A, Keogh S, Milton S, Walters D (2008) Upgrades to the boundary-layer scheme in the met office numerical weather prediction model. Bound Layer Meteorol 128(1):117-132. doi:10.1007/s10546-008-9275-0

Brown AR, Beljaars ACM, Hersbach H (2006) Errors in parametrizations of convective boundary-layer turbulent momentum mixing. Q J R Meteorol Soc 132:1859-1876

Cakmur RV, Miller R, Torresm O (2004) Incorporating the effect of small-scale circulations upon dust emissions in an atmospheric general circulation model. J Geophys Res Atmos 109(D07):201

Collins W, Bellouin N, Doutriaux-Boucher M, Gedney N, Halloran P, Hinton T, Hughes J, Jones C, Joshi M, Liddicoat S, Martin G, O'Connor F, Rae J, Senior C, Sitch S, Totterdell I, Wiltshire A, Woodward S (2011) Development and evaluation of an EarthSystem model-HadGEM2. Geosci Model Dev 4:1051-1075. doi:10.5194/gmd-4-1051-2011

De Longueville F, Hountondji YC, Henry S, Ozer P (2010) What do we know about effects of desert dust on air quality and human health in West Africa compared to other regions? Sci Total Environ 409(1): 1-8

Decker M, Brunke MA, Wang Z, Sakaguchi K, Zeng X, Bosilovich MG (2012) Evaluation of the reanalysis products from GFSC, NCEP and ECMWF using flux tower observations. J Clim 25:1916-1944

Dee DP, Uppala SM, Simmons AJ, Berrisford P, Poli P, Kobayashi S, Andrae U, Balmaseda MA, Balsamo G, Bauer P, Bechtold P, Beljaars ACM, van de Berg L, Bidlot J, Bormann N, Delsol C, Dragani R, Fuentes M, Geer AJ, Haimberger L, Healy SB, Hersbach H, Holma EV, Isaksen L, Kallberg P, Köhler M, Matricardi M, McNally AP, Monge-Sanz BM, Morcrette JJ, Park BK,
Peubey C, de Rosnay P, Tavolato C, Thepaut JN, Vitart F (2011) The ERA-interim reanalysis: configuration and performance of the data assimilation system. Q J R Meteorol Soc 137:553-597

Evan AT, Flamant C, Fiedler S, Doherty O (2014) An analysis of aeolian dust in climate models. Geophys Res Lett. doi:10.1002/201 4GL060545

Fécan F, Marticorena B, Bergametti G (1999) Parameterization of the increase of the aeolian erosion threshold wind friction velocity due to soil moisture for arid and semi-arid areas. Ann Geophys 17:149-157

Fiedler S, Schepanski K, Heinold B, Knippertz P, Tegen I (2013) Climatology of nocturnal low-level jets over North Africa and implications for modeling mineral dust emission. J Geophys Res Atmos 118. doi:10.1002/jgrd.50394

Fiedler S, Schepanski K, Knippertz P, Heinold B, Tegen I (2014) How important are atmospheric depressions and mobile cyclones for emitting mineral dust aerosol in North Africa? Atmos Chem Phys 14:8983-9000. doi:10.5194/acp-14-8983-2014

Gillette DA, Adams J, Endo A, Smith D (1980) Threshold velocities for input of soil particles in the air by desert soils. J Geophys Res 85:5621-5630

Ginoux P, Chin M, Tegen I, Prospero J, Holben B, Dubovik O, Lin SJ (2001) Sources and distributions of dust aerosols simulated with the GOCART model. J Geophys Res 106D:20,255-20,274

Griffin DW (2007) Atmospheric movement of mircoorganisms in clouds of desert dust and implications for human health. Clin Microbiol Rev 20(3):459477. doi:10.1128/CMR.00039-06

Heinold B, Knippertz P, Marsham JH, Fiedler S, Dixon NS, Schepanski K, Laurent B, Tegen I (2013) The role of deep convection and nocturnal low-level jets for dust emission in summertime West Africa: estimates from convection-permitting simulations. J Geophys Res Atmos 118:1-16. doi:10.1002/jgrd.50402

Holtslag A, Svensson G, Baas P, Basu S, Beare B, Beljaars A, Bosveld F, Cuxart J, Lindvall J, Steeneveld G et al (2013) Stable atmospheric boundary layers and diurnal cycles: challenges for weather and climate models. Bull Am Meteorol Soc 94:16911706. doi:10.1175/BAMS-D-11-00187.1

Hourdin F, Gueye M, Diallo B, Dufresne JL, Menut L, Marticoréna B, Siour G, Guichard F (2014) Parametrization of convective transport in the boundary layer and its impact on the representation of diurnal cycle of wind and dust emissions. Atmos Chem Phys Discuss 14(19):27425-27458. doi:10.5194/acpd-14-27425-2014

Huneeus N, Schulz M, Balkanski Y, Griesfeller J, Prospero J, Kinne S, Bauer S, Boucher O, Chin M, Dentener F, Diehl T, Easter R, Fillmore D, Ghan S, Ginoux P, Grini A, Horowitz L, Koch D, Krol MC, Landing W, Liu X, Mahowald N, Miller R, Morcrette JJ, Myhre G, Penner J, Perlwitz J, Stier P, Takemura T, Zender CS (2011) Global dust model intercomparison in AeroCom phase I. Atmos Chem Phys 11(15):7781-7816. doi:10.5194/ acp-11-7781-2011

Jickells T, An Z, Andersen K, Baker A, Bergametti G, Brooks N, Cao J, Boyd P, Duce R, Hunter K, Kawahata H, Kubilay N, laRoche J, Liss P, Mahowald N, Prospero J, Ridgwell A, Tegen I, Torres R (2005) Global iron connections between desert dust, ocean biogeochemistry, and climate. Science 308(5718):67-71

Jones CD, Hughes JK, Bellouin N, Hardiman SC, Jones GS, Knight J, Liddicoat S, O'Connor FM, Andres RJ, Bell C, Boo KO, Bozzo A, Butchart N, Cadule P, Corbin KD, Doutriaux-Boucher M, Friedlingstein P, Gornall J, Gray L, Halloran PR, Hurtt G, Ingram WJ, Lamarque JF, Law RM, Meinshausen M, Osprey S, Palin EJ, Parsons Chini L, Raddatz T, Sanderson MG, Sellar AA, Schurer A, Valdes P, Wood N, Woodward S, Yoshioka M, Zerroukat M (2011) The HadGEM2-ES implementation of CMIP5 centennial simulations. Geosci Model Dev 4(3):543-570. doi:10.5194/gmd-4-543-2011 
Kallos G, Papadopoulos A, Katsafados P, Nickovic S (2006) Transatlantic saharan dust transport: model simulation and results. J Geophys Res Atmos 111(D9). doi:10.1029/2005JD006207

Kalnay E, et al (1996) The NCEP/NCAR 40-year reanalysis project. Bull Am Meteor Soc 77:437-471. doi:10.1175/1520-0477(1996)077<:TNYRP >2.0.C

Kaplan JO (2001) Geophysical applications of vegetation modeling. Lund University, Techinical report

Karydis VA, Kumar P, Barahona D, Sokolik IN, Nenes A (2011) On the effect of dust particles on global cloud condensation nuclei and cloud droplet number. J Geophys Res 116(D23):204. doi:10. 1029/2011JD016283

King JC, Connolley WM, Derbyshire SH (2001) Sensitivity of modelled Antarctic climate to surface and boundary-layer flux parametrizations. Q J R Meteorol Soc 127(573):779-794. doi:10.1002/qj.49712757304

Knippertz P (2008) Dust emissions in the West African heat trough: the role of the diurnal cycle and of extratropical disturbances. Meteorol Z 17(5):553-563

Largeron Y, Guichard F, Bouniol D, Couvreux F, Kergoat L, Marticorena B (2015) Can we use surface wind fields from meteorological reanalyses for Sahelian dust emission simulations? Geophys Res Lett 2014G. doi:10.1002/2014GL062938,L062938

Lohmann U, Feichter J (2005) Global indirect aerosol effects: a review. Atmos Chem Phys 5:715-737

Louis J, Tiedtke M, Geleyn J (1982) A short history of the PBL parameterization at ECMWF. In: Proceedings of workshop on boundary-layer parameterization. ECMWF, Reading, UK, p 5979

Loveland TR, Reed BC, Brown JF, Ohlen DO, Zhu Z, Yang L, Merchant JW (2000) Development of a global land cover characteristics database and IGBP discover from $1 \mathrm{~km}$ AVHRR data. Int J Remote Sens 21(6-7):1303-1330. doi: $10.1080 / 014311600210191$

Mahowald N, Baker A, Bergametti G, Brooks N, Duce R, Jickells T, Kubilay N, Prospero J, Tegen I (2005) Atmospheric global dust cycle and iron inputs to the ocean. Global Geochem Cycle 19:GB4025

Marsham JH, Knippertz P, Dickson N, Parker DJ, Lister G (2011) The importance of the representation of deep convection for modeled dust-generating winds over West Africa during summer. Geophys Res Lett 38(L16):803. doi:10.1029/2011GL048368

Marsham JH, Dixon NS, Garcia-Carreras L, Lister GMS, Parker DJ, Knippertz P, Birch CE (2013) The role of moist convection in the west african monsoon system: insights from continentalscale convection-permitting simulations. Geophys Res Lett 40(9):1843-1849. doi:10.1002/grl.50347

Marticorena B, Bergametti G (1995) Modelling the atmospheric dust cycle. 1: design of a soilderived dust emission scheme. J Geophys Res 100:16,415-16,430

Martin GM, Levine RC (2012) The influence of dynamic vegetation on the present-day simulation and future projections of the south asian summer monsoon in the hadgem 2 family. Earth Syst Dyn 3(2):245-261. doi:10.5194/esd-3-245-2012

Martin GM, Bellouin N, Collins W, Culverwell I, Halloran P, Hardiman S, Hinton T, Jones C, McDonald R, AJ M, OConnor F, Roberts M, Rodriguez J, Woodward S, Best M, Brooks M, Brown A, Butchart N, Dear-den C, Derbyshire S, Dharssi I, DoutriauxBoucher M, Edwards J, Falloon P, Gedney N, Gray L, Hewitt $\mathrm{H}$, Hobson M, Huddleston M, Hughes J, Ineson S, Ingram W, James P, Johns T, Johnson C, Jones A, Jones C, Joshi M, Keen A, Liddicoat S, Lock A, Maidens A, Manners J, Milton S, Rae J, Ridley J, Sellar A, Senior C, Totterdell I, Verhoef A, Vidale P, Wiltshire A (2011) The HadGEM2 family of Met Office Unified Model climate configurations. Geosci Model Dev 4:723-757. doi:10.5194/gmd-4-723-2011
Mulcahy JP, Walters DN, Bellouin N, Milton SF (2014) Impacts of increasing the aerosol complexity in the met office global numerical weather prediction model. Atmos Chem Phys 14(9):47494778. doi:10.5194/acp-14-4749-2014

Okin GS, Mahowald N, Chadwick OA, Artaxo P (2004) Impact of desert dust on the biogeochemistry of phosphorus in terrestrial ecosystems. Global Biogeochem Cycle 18:GB2005

Parker D, Burton R, Diongue-Niang A, Ellis R, Felton M, Taylor C, Thorncroft C, Bessemoulin P, Tompkins A (2005) The diurnal cycle of the West African monsoon circulation. Q J R Meteorol Soc 131(611, Part a):2839-2860. doi:10.1256/qj.04.52

Parker DJ, Fink A, Janicot S, Ngamini J, Douglas M, Afiesimama E, Agusti-Panareda A, Beljaars A, Dide F, Diedhiou A, Lebel T, Polcher J, Redelsperger J, Thorncroft C, Wilson G (2008) The AMMA radiosonde program and its implications for the future of atmospheric monitoring over Africa. Bull Am Meteorol Soc 89:1015-1027. doi:10.1175/2008BAMS2436.1

Pospichal B, Karam DB, Crewell S, Flamant C, Huenerbein A, Bock O, Said F (2010) Diurnal cycle of the intertropical discontinuity over West Africa analysed by remote sensing and mesoscale modelling. Q J R Meteorol Soc 136(1, SI):92-106. doi:10.1002/qj.435

Prospero J (1996) Saharan dust transport over the North Atlantic Ocean and Mediterranean: an overview. In: Guerzoni S, Chester R (eds) The impact of desert dust across the Mediterranean, environmental science and technology library, vol 11. Springer, Netherlands, pp 133-151

Redelsperger JL, Thorncroft CD, Diedhiou A, Lebel T, Parker DJ, Polcher J (2006) African monsoon multidisciplinary analysis: an international research project and field campaign. Bull Am Meteorol Soc 87:1739. doi:10.1175/BAMS-87-12-1739

Rienecker MM, Suarez MJ, Gelaro R, Todling R, Bacmeister J, Liu E, Bosilovich MG, Schubert SD, Takacs L, Kim GK, Bloom S, Chen J, Collins D, Conaty A, da Silva A, Gu W, Joiner J, Koster RD, Lucchesi R, Molod A (2011) MERRA: NASA's modernera retrospective analysis for research and applications. J Clim 24(14):3624-3648

Rosenfeld D, Rudich Y, Lahav R (2001) Desert dust suppressing precipitation: a possible desertification feedback loop. PNAS 98(11):5975-5980

Saha S, Moorthi S, Pan HL, Wu X, Wang J, Nadiga S, Tripp P, Kistler R, Woollen J, Behringer D et al (2010) The ncep climate forecast system reanalysis. Bull Am Meteorol Soc 91(8):1015-1057

Sandu I, Beljaars A, Bechtold P, Mauritsen T, Balsamo G (2013) Why is it so difficult to represent stably stratified conditions in numerical weather prediction (NWP) models? J Adv Model Earth Syst. doi:10.1002/jame.20013

Schepanski K, Tegen I, Todd M, Heinold B, Bönisch G, Laurent B, Macke A (2009) Meteorological processes forcing Saharan dust emission inferred from MSG-SEVERI observations of subdaily dust source activation and numerical models. J Geophys Res 114(D10):201

Schepanski K, Knippertz P, Fiedler S, Timouk F, Demarty J (2014) The sensitivity of nocturnal low-level jets and near-surface winds over the Sahel to model resolution, initial conditions and boundary-layer set-up. Q J R Meteorol Soc. doi:10.1002/qj.2453

Schepanski K, Tegen I, Laurent B, Heinold B, Macke A (2007) A new Saharan dust source activation frequency map derived from MSG-SEVIRI IR-channels. Geophys Res Lett 34(18):L18803. doi:10.1029/2007GL030168

Schmechtig C, Marticorena B, Chatenet B, Bergametti G, Rajot JL, Coman A (2011) Simulation of the mineral dust content over Western Africa from the event to the annual scale with the CHIMERE-DUST model. Atmos Chem Phys 11:7185-7207

Schulz M, Prospero JM, Baker AR, Dentener F, Ickes L, Liss PS, Mahowald NM, Nickovic S, García-Pando CP, Rodríguez S, et al. (2012) Atmospheric transport and deposition of mineral 
dust to the ocean: implications for research needs. Environ Sci Technol 46(19):10390-10404

Shao Y, Wyrwoll KH, Chappell A, Huang J, Lin Z, McTrainsh GH, Mikami M, Tanaka TY, Wang X, Yoon S (2011) Dust cycle: a emerging core theme in earth system science. Aeolian Res 2:181-204

Sokolik I, Toon O (1996) Direct radiative forcing by anthropogenic airborne mineral aerosols. Nature 381:681-683

Steeneveld GJ, van de Wiel BJH, Holtslag AAM (2006) Modeling the evolution of the atmospheric boundary layer coupled to the land surface for three contrasting nights in CASES-99. J Atmos Sci 63(3):920-935

Steeneveld GJ, Mauritsen T, de Bruijn EIF, Vil-Guerau de Arellano J, Svensson G, Holtslag AAM (2008) Evaluation of limited-area models for the representation of the diurnal cycle and contrasting nights in CASES-99. J Appl Meteorol Climatol 47(3):869-887

Stull RB (1988) An introduction to boundary layer meteorology. Kluwer, Dordrecht

Svensson G, Holtslag A, Kumar V, Mauritsen T, Steeneveld G, Angevine W, Bazile E, Beljaars A, Bruijn E, Cheng A, Conangla L, Cuxart J, Ek M, Falk M, Freedman F, Kitagawa H, Larson V, Lock A, Mailhot J, Masson V, Park S, Pleim J, Sderberg S, Weng W, Zampieri M (2011) Evaluation of the diurnal cycle in the atmospheric boundary layer over land as represented by a variety of single-column models: the second GABLS experiment. Bound Layer Meteorol 140(2):177-206. doi:10.1007/ s10546-011-9611-7

Tanaka T, Chiba M (2006) A numerical study of the contributions of dust source regions to the global dust budget. Global Planet Change 52:88-104

Tegen I, Harrison S, Kohfeld K, Prentice I, Coe M, Heimann M (2002) Impact of vegetation and preferential source areas on global dust aerosols: results from a model study. J Geophys Res 107(D21):4576

Textor C, Schulz M, Guibert S, Kinne S, Balkanski Y, Bauer S, Berntsen T, Berglen T, Boucher O, Chin M, Dentener F, Diehl T, Easter R, Feichter H, Fillmore D, Ghan S, Ginoux P, Gong S, Grini A, Hendricks J, Horowitz L, Huang P, Isaksen I, Iversen I,
Kloster S, Koch D, Kirkevåg A, Kristjansson JE, Krol M, Lauer A, Lamarque JF, Liu X, Montanaro V, Myhre G, Penner J, Pitari G, Reddy S, Seland Ø, Stier P, Takemura T, Tie X (2006) Analysis and quantification of the diversities of aerosol life cycles within AeroCom. Atmos Chem Phys 6:1777-1813

Timmreck C, Schulz M (2004) Significant dust simulation differences in nudged and climatological operation mode of the AGCM ECHAM. J Geophys Res Atmos 109(D13). doi:10.1029/2003JD004381, d13202

Todd MC, Washington R, Raghavan S, Lizcano G, Knippertz P (2008) Regional model simulations of the Bodele low-level jet of northern Chad during the Bodélé Dust Experiment (BoDEx 2005). J Clim 21(5):995-1012. doi:10.1175/2007JCLI1766.1

Tompkins A, Cardinali C, Morcrette J, Rodwell M (2005) Influence of aerosol climatology on forecasts of the African Easterly Jet. Geophys Res Lett 32(L10):801

Van de Wiel B, Moene A, Steeneveld G, Baas P, Bosveld F, Holtslag A (2010) A conceptional view on inertial oscillations and nocturnal low-level jets. J Atmos Sci 67:2679-2689

Viterbo P, Beljaars A, Mahfouf JF, Teixeira J (1999) The representation of soil moisture freezing and its impact on the stable boundary layer. Q J R Meteorol Soc 125(559):2401-2426. doi:10.1002/qj.49712555904

Washington R, Todd M (2005) Atmospheric controls on mineral dust emission from the Bodele depression, Chad: the role of the lowlevel jet. Geophys Res Let 32(L17):701

Woodward S (2001) Modeling the atmospheric life cycle and radiative impact of mineral dust in the Hadley Centre climate model. J Geophys Res Atmos 106(D16):18,155-18,166. doi:10.1029/20 00JD900795

Woodward S (2011) Mineral dust in HadGEM2. Technical note 87, Hadley Centre

Zender C, Miller R, Tegen I (2004) Quantifying mineral dust mass budgets: terminology constraints and current estimates. EOS Trans AGU 85(48):509-512

Zobler L (1986) A world soil file for global climate modeling. Techinical report NASA TM 87802, 32 pp, NASA, NASA, Washington, DC 